\title{
Principles of Manufacturing Biocompatible and Biostable Polymer Implants (Review)
}

\author{
DOI: $10.17691 / \mathrm{stm} 2015.7 .3 .20$
}

Received Desember 26, 2014

V.M. Treushnikov, Deputy Director;

E.A. Viktorova, Deputy Director

Research and Production Enterprise "Reper-NN", 85 Moskovskoe Shosse, Nizhny Novgorod, 603079,

Russian Federation

The review concerns the basic theoretical aspects of manufacturing biocompatible and biostable implants and represents, mainly, the experience of our research team. Biocompatible implants have been shown to be understood to mean both: those, which are not rejected by the body as well as those, which are not capsulated in the body. They are to be fabricated according to one-stage frontal photopolymerization with extreme low reaction front to avoid defect formation in a polymer. Moreover, an additional unstable stage is required to result in the death of end free macroradicals and labile products in a polymer. For implant fabrication we used photopolimerizable compositions resulting in the formation of hydrophobic spatially cross-linked polymers, their correlation time of spinning motion of a paramagnetic probe of 2,2,6,6-tetramethyl-4oxypiperidine-1-oxide approximately being $6 \cdot 10^{-10} \mathrm{~s}$. The fulfillment of these conditions means the use of radically polymerizable oligomerbased compositions (oligoester methacrylates, oligocarbonate methacrylates, oligourethane methacrylates, etc.). Compositions having lower or higher correlation time of the specified probe are not appropriate for the fabrication of biocompatible and biostable implants. The characteristics of oligomer-monomer compounds have a greater effect on physicochemical properties of implants rather than on their biocompatibility and biostability. No implant incapsulation is determined by the initial composition formulation provided that the mentioned conditions are fulfilled. A polymer in biostable and biocompatible implants can be only optically transparent, though the converse is not necessary.

Key words: biocompatibility; biostability; biodegradation; polymer implant; radical polymerization; polymer lysis; monomer; oligomer.

Polymer implants have increasingly widespread application in medicine. It is impossible to imagine current ophthalmosurgery without intraocular lens [130], scleroplants [31-36], intrastromal and intracapsular rings [37-53], glaucomatous drainages and shunts [54-64]; neurosurgery - without dura matter [6573], tension-free abdominal hernioplasty - without specific polymer meshes [74-87]; maxillofacial surgery, orthopedic surgery, neurosurgery - without polymer plates replacing or substituting bones [88-96], etc. Polymer application in medicine can be wider if the problem of their biocompatibility and biostability could be completely solved.

Polymers used in medicine can be divided into two large groups: biodegradable (resorbable) and nonabsorbable [97-103]. By the definition biodegradable polymers cannot be biostable: their destruction is likely to result in the formation of low-molecular compounds taken by the body as those pertaining to the body: they participate in metabolic processes, or there is the process of their elimination. For example, for production of some implants, polylactic acid is used, the hydrolysis of which results in the formation of lactic acid representing a natural metabolite of Krebs cycle [101]. To develop biodegradable implants, various polymers find their wide application, both the polymers derived from plants and animals, as well as synthetic ones, e.g., polyethers of cyanoacrylate and hydroxy carboxylic acids, and others [101]. Implants manufactured from these polymers can be rather biocompatible but not biostable. The review concerns with the development of implants, which should not have any discharges (biostable). Certainly, we cannot ignore biodegradable polymers. Both polymers have their own application: biodegradable polymers are more appropriate for sutures, e.g., polyglycol acidbased polymers [101], while they are cannot be used for intraocular lens (IOL) production. Biostable polymers are to be used for IOL [104].

When producing implants there should be taken into consideration both a polymer type an implant to be made of and also the way of implant manufacturing. Polymer implants, as a rule, are various threedimensional structures with different architecture and morphology. For example, IOL are usually biconvex lens with supporting elements (haptics) made of an optically transparent polymer [8, 11, 13, 17-20, 28]; dura mater are various membranes and films of different relief design [68, 69, 73]; glaucomatous microshunts and drainages are porous or perforated films, various tubes, and other allowable constructions aimed at removing eye fluid from the posterior chamber in blood vessels $[54-63,105]$, etc.

For contacts: Viktorova Elena Alexandrovna, e-mail: reper-nn@mail.ru 
Two essentially different schemes of manufacturing polymer implants are known: a conventional two-stage procedure, when a polymer is first synthesized followed by the formation of a polymer product using different techniques, and a one-stage operation, when a polymer and a product are synthesized simultaneously (onestep procedure) $[104,106]$. Thermopressing, pressure casting, mechanical processing, and electrospinning [107-112], the formation on spinnerets of polymer threads and fibers, and use them to plait products [113, 114], washing-out different crystals from polymers filled with these crystals [115], supercritical fluid technologies [116-122], etc., are widely used to form products according to a conventional one-stage technique.

The review considers, mainly, a one-stage scheme to produce polymer implants. To some extent, it is due to the fact that one-stage manufacturing is reported insufficiently in literature that can be explained by a negative attitude to a one-stage scheme of producing polymer materials. Currently, this attitude prevails, since the scheme is considered to be of little promise, and unsuitable for producing precise and optically transparent implants. The main insuperable obstacle is thought to be the reaction medium shrinkage and thermal extraction in any technique of polymer synthesis. These phenomena bear a direct relation to a one-stage scheme, since it suggests using monomer of a certain type rather than polymers. It is impossible to avoid reaction mass shrinkage and thermal extraction when polymerizing most monomers, though it is possible to form polymer products in a way to eliminate adverse effects of these phenomena on the quality of products. The basic requirements for monomers and synthesis conditions of polymer products, but not polymer, are described in what follows.

It is not by chance that light is used to manufacture products according to a one-stage scheme to initiate polymerization. Light flux can be controlled and pointed at the areas a polymer is to be formed, and vice versa, all efforts can be taken to prevent light from penetrating the areas a polymer is to be absent. In recent times, a one-stage scheme to manufacture polymer products has been directly related to photochemistry, photopolymerization, photolithography, though it is still impossible to control light-independent reactions over a distance. In this regard, currently, there being developed different techniques to produce polymer implants using photolithography. The modifications of the method aim at manufacturing three-dimensional products rather than flat (two-dimensional) ones [123-125]. It is unlikely that a universal technique of producing polymer implants according to a one-stage scheme will be developed. There should be taken into account that the architecture of implants and their geometrical dimensions will be very much different depending on what tissue they are to be implanted in and what space to occupy. The development of the techniques to manufacture implants of different shapes and sizes by a one-stage scheme, where light is the main 'tool', is in its inchoative stage. It may happen that in the future not only light but other types of radiation (X-rays, electron radiation, etc.) will be applied to manufacture implants.

The development of tissue engineering presupposes the use of a defined shape of polymer frameworks (scaffolds) able to play the role of embryos to form new tissues instead of damaged or dysfunctional, and imposes a number of new requirements on implants. Currently, implant architecture and the absence of discharges cannot be considered sufficient requirements. Implants should both not fail and also be isolated from surrounding tissues. It is safe to say that tissue engineering significantly changes the concept of biocompatibility [101, 126]. Implants (frameworks) should attach firmly biological cells of a certain type (i.e., exhibit high cell sticking, or adhesion), should not prevent their division (multiplication), and, on the contrary, should prevent attachment and multiplication of other type cells (i.e., stimulate selectively the growth of defined tissues alone) [126].

There are two points of view what properties scaffolds need: cells can be cultured in vitro (out of the body) and then implanted in damaged tissues [127, 128], or scaffolds are to be inserted in a body and serve as a germ for growth and development of the lost tissue. The first point of view is supposed to be not without disadvantages. The main point is what is to be done with the principal reaction of any organism on temporal or permanent penetration of a foreign body in the organism's tissue resulting in the formation of connective tissue around the foreign body (encapsulation). Encapsulation is certain not to lead to implant failure but can cause unfavorable isolation from the surrounding environment. Such encapsulation, in particular, occurs in case of glaucomatous drainage implantation and results in drainage failure [129]. Encapsulation nullifies all positive effects expected after implantation. This raises the question: what properties an implant should have not to fail, and not to be taken for a foreign body. The answer cannot be given without knowing the mechanisms of cell attachment to implants.

It is generally believed that cell adhesion to implants is determined either by electrostatic or somewhat specific interactions, when there are specific fragments for adherence to fit as if a key and a keyhole [101, 130]. One can concede that in case of specific interactions the adhesion of cells to an implant is determined by the possibility to form hydrogen bonding. Specific interactions are realized when bioactive molecules are immobilized and peptides are attached on a polymer surface [101, 102]. The presence of electrostatic interactions can be explained by the fact that on cell membranes there is the so called resting potential: the potential difference between cell cytoplasm and the cell environment. The potential difference occurs due to 
the fact that permeability of cell membranes is different for different ions, and selected ions transport actively through the membrane resulting in the concentration of a negative charge on its inner surface, and a positive charge on the outer membrane surface. Thus, it can be assumed that cell will adhere to an implant if the implant surface is positively charged. Under these conditions of cell adhesion to implants, it is quite possible that cells will grow and evolve into tissue if in vitro but not in vivo. These mechanisms do not solve the encapsulation problem.

The described mechanisms of cell adhesion to implants are not the only ones. There can also be adhesion by the type of biological membrane formation. All biological membranes (matrices) are based on a double layer of lipids, generally, phospholipids. Phospholipid molecules have a hydrophilic head and hydrophobic ends (one-dimensional chains consisting of 8-18 $\mathrm{CH}_{2}$ fragments). Thermodynamically, energetically favorable condition of these molecules in water is that when they form a double layer, with hydrophobic ends being in the central area and directing each other, while hydrophilic heads being on the periphery and pointing at the surrounding medium (water). Such structure is typical in water solutions only. In non-polar solvents it is the opposite: there is a double layer but hydrophilic ends are inside, while hydrophobic ones are on the periphery. It indicates that in the formation of any structures the interactions are not so important, as the common value of a certain system at a given environment, which cannot be ignored. In this regard, cells are to be expected to adhere to the implants, on the surface of which there is a layer of saturated hydrocarbons of the same length as those in biomembranes (scaffold surface should have linear hydrocarbons of different length). If such scaffolds are placed in water culture medium or in tissues of a living body, then on their surface lipids first will be adsorbed forming the structure appropriate for a membrane matrix followed by the adsorption of a protein layer the cells will be able to adhere.

It should be said that these ideas are consistent with the experiment [131]. Progenitor cells adhere to the frameworks prepared according to a one-stage scheme. They promote cell differentiation, stimulate growth (finally, there forms nervous tissue able to perform the functions it is supposed to). Polymer implants (frameworks) with such properties prevent encapsulation: the state of a rat brain remained unchanged for a year after implantation. That is easy to explain too. Generally, biological molecules should be in a bound state rather than in a free state: they should be the parts of some structures, e.g., biomembranes. It can be assumed that connective tissue formation is caused by some molecules, which are in a free state (they are most likely to signal the necessity for connective tissue formation). The penetration of a foreign body in tissues is related to cell damage and the appearance of free biomolecules. An inverse process - the transfer of the molecules from a free state into bound one - leads to the deactivation of a signal of a foreign body penetration in the body. The process should occur when the abovementioned implants are inserted due to the adhesion to the surface of lipids first, and then to that of proteins, and further, of other molecules as well.

The implants with the properties described above acquire in the body nearly the same membranes as the surrounding cells. These membranes can be no different in chemical composition from biomembranes but between the outer and inner surfaces there is no resting potential typical for living cells. That is the utmost we can do so far. It is still impossible to reproduce active transport of ions. However, there is confidence that resting potential will not promote cell adhesion to an implant so much as suggested in the work reported [101]. It is our opinion that the most reliable technique to develop biostable implants is that specified in the work [131].

We suppose that the above stated is enough to conclude about the prospects of one-stage processes for implant formation. Using lithography it is possible to manufacture implants of any complexity, and also with dimensions typical for cell formations. Microelecrtonics is an example, its existence is difficult to imagine without lithographic processes. These processes will find their wider application in polymer implant manufacturing, if the basic regularities of oligomer and monomer photopolymerization are taken into account. The regularities will be considered below.

We believe the development of biocompatible and biostable implants to be impossible without regard to the phenomena of chemical reaction arresting and reactive capacity leveling occurring when changing from low- to high-viscosity media [132-135], and achieving steadystate density of macromolecule packing in implants. The theory is set forward in the work [134]. The backbone of the theory consists in the following: effective velocity constants of biomolecular reactions in condensed media equal the product of velocity constants of reactions $k_{1}$ by cell effect value $P_{\text {cell eff }}$, with the mechanism of such reactions being described by one of the following schemes:

$$
\begin{aligned}
& A+B \rightarrow\left[A \ldots B \underset{k_{2}}{\stackrel{k_{1}}{\rightleftarrows}}(A B)^{\star}\right] \stackrel{k_{3}}{\longrightarrow} \text { Products; } \\
& A+B \rightarrow\left[A \ldots B \underset{k_{2}}{\stackrel{\frac{k_{1}}{\longrightarrow}}{\longrightarrow}}(A B)^{\star}\right] \stackrel{D}{\Longrightarrow} \text { Products. }
\end{aligned}
$$

In the course of reaction the reagents first enter a single cell, from which through an activated state they pass into the formation of end products. The lower scheme differs from the upper one by nothing but the fact that the transfer from an activated state in reaction products results from the diffusion motion (indicated by a double arrow) characterized by diffusion coefficient $D$ rather than from the process characterized by a reaction velocity constant $k_{3}$. The difference is of fundamental importance. The fact is the probability density function 
to detect reaction products in the first instance is determined by the following exponential function (correct for Poisson processes only):

$$
f(t)=k_{3} \cdot e^{-k_{3} \cdot t},
$$

while in the latter case it is determined by Fokker-Planck equation solutions (fails to meet the requirements for Poisson processes). The easiest variant to represent the probability density function to detect reaction products in this case is the function [136]:

$$
f(t)=\frac{z}{2 \cdot \sqrt{\pi \cdot D \cdot t^{3}}} \cdot e^{-\frac{z^{2}}{4 \cdot D \cdot t},}
$$

where $z$ is the distance, which the reagents should cover towards the end products to leave a cell. The use of ordinary differential equations (in kinetics it is a mass-action law) is possible in case Poisson processes are described. In this regard, the values of $P_{\text {cell eff }}$ for the schemes given above are to be determined by the following integrals [137-140]:
$P_{\text {cell eff }}^{(1)}(\delta)=\int_{0}^{\infty} k_{3} \cdot e^{-k_{3} \cdot t} \int_{t}^{\infty} k_{2} \cdot e^{-k_{2} \cdot t} d \varepsilon \cdot d t=\frac{\delta}{1+\delta}$; (3)

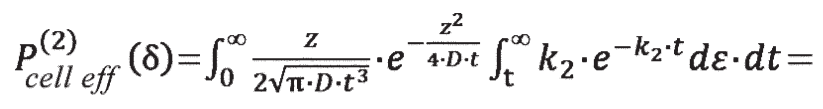

$$
=\frac{1}{\sqrt{\pi}} \int_{0}^{\infty} t^{-\frac{3}{2}} \cdot e^{-\left(\frac{1}{t}+\frac{t}{\delta}\right)} d t,
$$

where $\delta=\frac{4 \cdot D}{z^{2} \cdot k_{2}}=\frac{k_{3}}{k_{2}}$.

The represented probability density function curves determined by equations (1) and (2), as well as the cell effect value versus $\delta$ relationship determined by equations (3) and (4) show (Figure 1) to what extent they may differ from each other if one probability density function changes another. It is easy to imagine what will happen if $\delta$ parameter is reduced. Its reduction at a constant temperature can be due to the medium viscosity increase or the growth of molecular sizes and the structure of reagents. If $\delta$ values are high, the cell effect values are

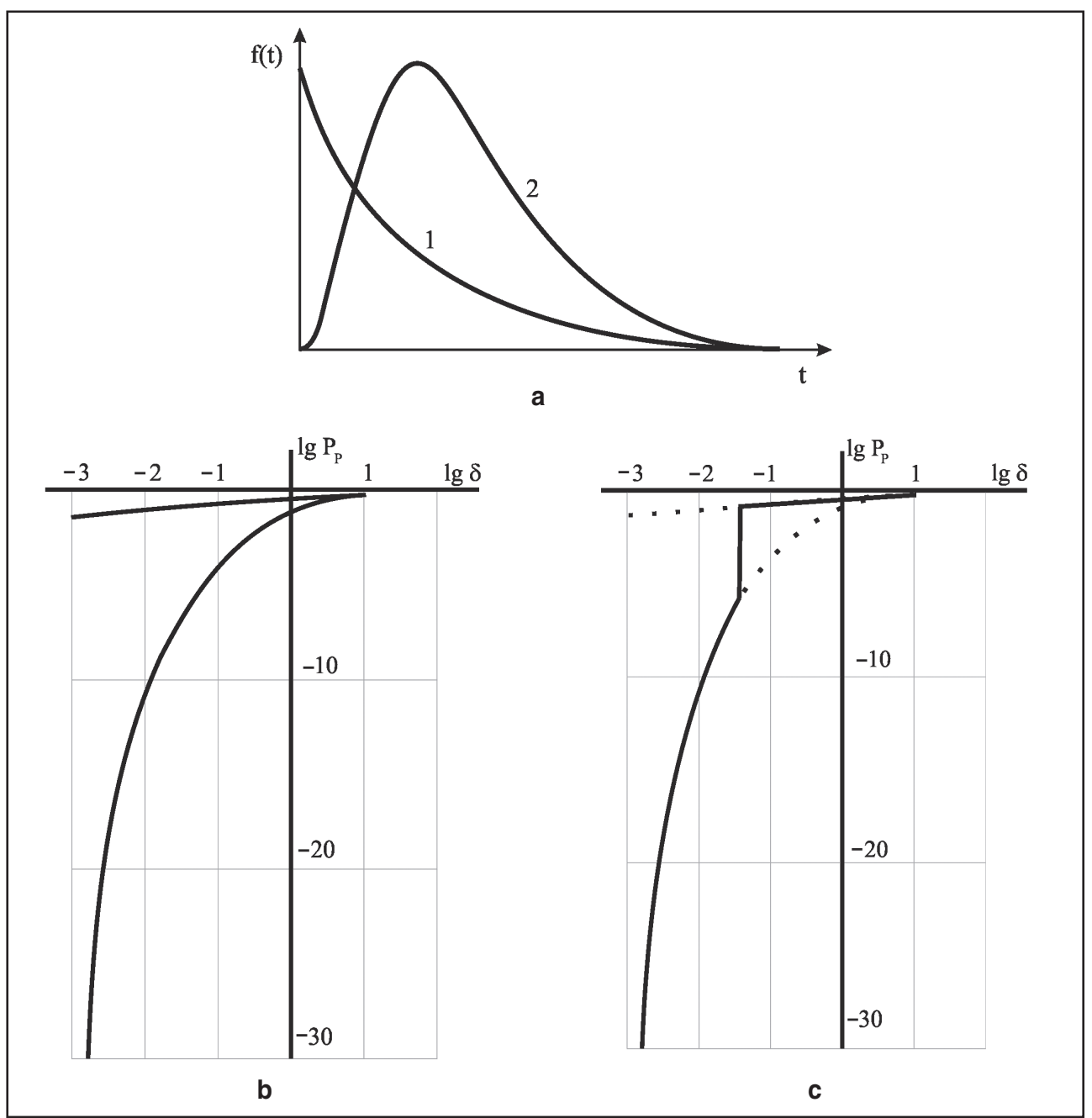

Figure 1. (a) Densities of probability distributions $\left(P_{p}\right)$ determined by the equations (1) and (2); (b) the cell effect value versus $\delta$ relationship determined by equations (3) and (4); (c) an expected dependence of a cell effect on $\delta$ parameter 
determined by the upper curve (it is required by classical kinetic theory), if they are low - by the lower curve. The transfer from the upper curve to the lower one should occur if $\delta$ is near some values. Figure 1 also shows an expected cell effect value versus $\delta$ relationship. Since the observed velocity constants of chemical reactions equal the products $k_{1} \cdot P_{\text {cell }}$ eff $(\delta)$, then such transfers are to be accompanied by a sharp retardation of the reaction course (looking like the reaction arresting). The transfer of reactions from low- into high-viscosity media (more precisely, if the motility of reagents is reduced) should result in chemical reaction velocity fall, the velocities being equal to the deviations of one $P_{\text {cell eff }}(\delta)$ curve from another [134]. It can be said that this approach settles the differences between chemical kinetics and that in living systems. Chemical processes in living systems occur under isothermal conditions, and due to this fact chemical kinetics cannot suggest the ways to control these reactions. A different situation arises with the use of equation (4) and the curves shown in Figure 1, which declare the dependence of velocity constants of the reactions on reagent motility, and one cannot do without it when studying the factors contributing to the velocities of chemical reactions in biological systems. The phenomenon of reactive capacity leveling is to be related to the fact that when medium viscosity is increasing, first of all, run-away reaction stops, and then slower ones, though the transfers to diffusion motion in rapid reaction occur at lower $\delta$ values compared to slower reactions. The latter, in particular, follows from the fact that reactive capacity leveling in high-viscosity media presupposes approximate equality of the product $k_{1} \cdot P_{\text {cell eff }}(\delta)$ (the more $k_{1}$ the lower $P_{\text {cell eff }}$ ).

Now it should be said what is to happen when polymers are manufactured by radical polymerization. A distinctive feature of a polymerization reaction from many other reactions is medium viscosity growth in the course of the reaction (the increase of monomer conversion degree). Since chain disconnection reaction is the most rapid stage of polymerization, then these reactions should be arrested first of all. This stage arresting is to lead to breakless polymerization, which should result in the termination of end macroradical death due to recombination and disproportionation reactions. Further increase of reaction medium viscosity is sure to result in arresting polymerization chain growth, it is evident by the fact that a monomer part remains free (unexpended). In some cases the free monomer content in a polymer can be reduced by additional procedures: polymer heating after polymerization (medium viscosity decrease due to temperature increase) or temporal introduction of an inert solvent in a polymer (medium viscosity decrease due to plasticization) [141]. These techniques are well known, and there is no sense in considering them.

Let us determine the consequences of these phenomena in respect to polymerization reactions, which should be carried out under any conditions. The velocity of a polymerization reaction $\left(V_{\text {pol }}\right)$ is known to equal [142]

$$
V_{p o l}=v_{i} \cdot \bar{\gamma}
$$

where $v_{i}$ and $\gamma$ are initiation velocity and mean length of a kinetic polymerization chain. If a polymerization reaction occurs in a steady-state regime (as a rule, this regime is considered to be the characteristic for radical polymerization), the following correlations are correct $[143,144]$ :

$$
V_{p o}=k_{g} \cdot C_{M} \cdot \sqrt{\frac{\mathrm{v}_{i}}{k_{d}}} ; \quad \bar{\gamma}=\frac{k_{p} \cdot C_{M}}{\sqrt{\mathrm{v}_{i} \cdot k_{d}}},
$$

where $k_{g}$ and $k_{d}$ are velocity constants of growth and polymerization chain disconnection (the formation rate of free radicals in a steady-state regime is supposed to be equal to death of microradicals resulting from recombination and disproportionation reactions).

Making use of the correlations (1)-(6), we may conclude:

1) the factors contributing to the reduction of reagent motility, primarily, should arrest the reaction of polymerization chain disconnection $\left(k_{d} \approx 0\right)$, that is likely to result in abnormally high polymerization velocity $\left(V_{p o} \approx \infty\right.$, as $k_{g}$ is a conservative value);

2) further reduction of reagent motility should lead to the decrease of $k_{g}$ (arresting the reactions of polymerization chain growth and the decrease of polymerization ve154locity), but the polymerization velocity should be proportional to polymerization chain initiation rate to the first power rather than the power equal to $1 / 2$ (mean length of polymerization kinetic chain does not depend on initiation rate);

3) the change of velocity constants $k_{g}$ and $k_{d}$ by the motility of the corresponding reagent occurs by the type of critical events depending on $\delta$ parameter only.

The manifestation of the abovementioned statements can be considered as those indicating the course of a breakless polymerization reaction. Primarily, the so called gel effect indicates the possibility of a breakless polymerization reaction. It is Trommsdorf effect resulting in the increase of polymerization velocity at high monomer conversion degrees, no less than two orders higher compared to the initial one that is consistent with the arrest of polymerization chain disconnection resulted from recombination and disproportionation reactions $[143,144]$. The effect occurs in case of the polymerization of nearly all low-viscosity monomers (methylmethacrylate, butyl methacrylate, methacrylic acid, etc). When these monomers are polymerized, at the end of the reaction it self-accelerates (if certain viscosity is achieved). Kinetic curves of photopolymerization in such monomers consist of four parts: an induction period; a steady-state polymerization regime (the regularities described by the equations (6) occur during this period); breakless polymerization (no chain disconnection resulted from recombination and 
disproportionation reactions does not preclude the chain disconnection due to other reaction, for example, free radical scavenging by the formed polymer); a closing stage (Figure 2).

One of basic assumptions is due to the fact that conclusion 3 concedes preparations of compositions with such initial viscosity; there is no steady-state regime at their polymerization, therefore, there is no self-acceleration at the end of the reaction: breakless polymerization starts immediately after the induction period (Figure 3). In case of these compositions, polymerization velocity should be abnormally high (polymerization can be performed within a few minutes and even seconds rather than over many hours) and

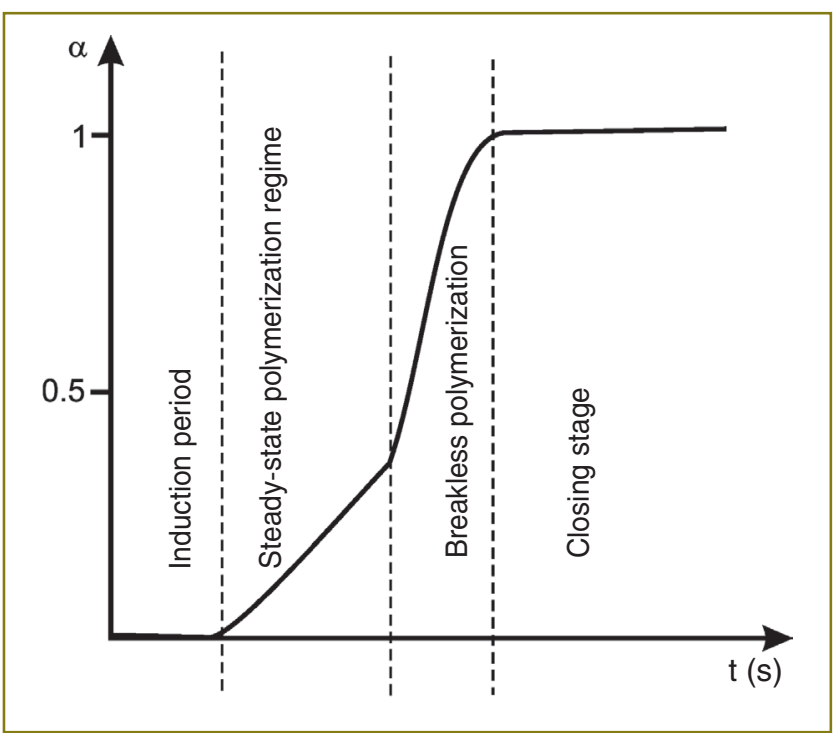

Figure 2. A typical kinetic curve showing the dependence of polymerization degree of low-viscosity monomers on time

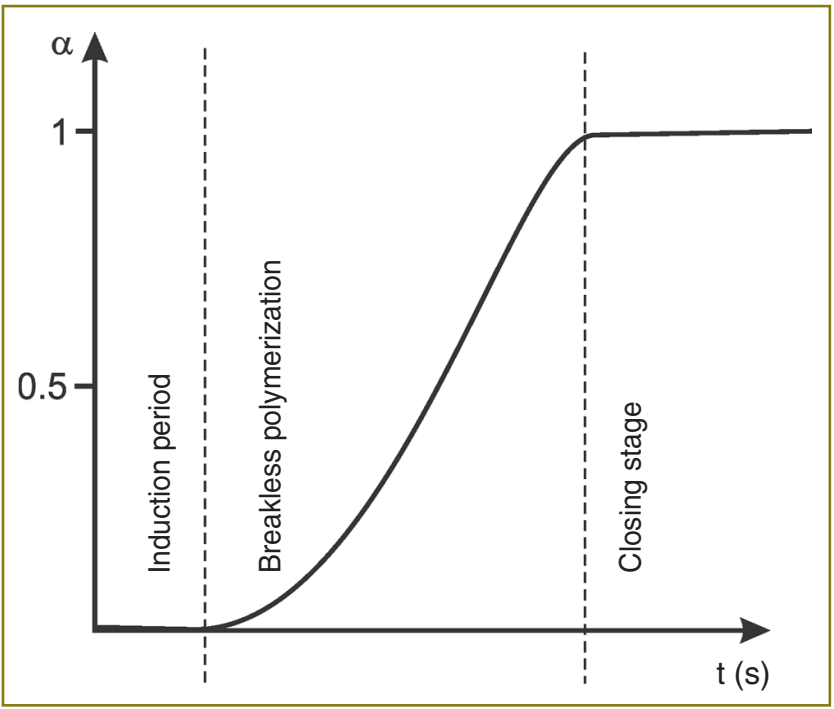

Figure 3. An ideal kinetic curve of dependence of monomer polymerization degree on the time to realize frontal polymerization depend linearly on the initiation rate of a polymerization chain. Such compositions were prepared when lowviscosity monomers were changed to oligomers (various oligoester methacrylates, and others represented in works $[145,146])$. Therefore, the questions raised in work [147]: why these oligomers are polymerized at abnormally high rate despite the fact that their reactive capacity is not higher than that of regular monomers can be answered with relation to the abovementioned: the reaction proceeds as a breakless reaction (the result of arresting the reactions of polymerization chain disconnection). It should be considered that a breakless mechanism of polymerization presupposes the formation of end macroradicals in a polymer. It is not the only mechanism of their formation. An induction period relates to the presence of a high-efficient inhibitor of radical polymerization in a reaction mixture. The so called pseudo-living radical polymerization has been proved to exist $[144,148]$. Its origin is related to the complex of an end macroradical of a polymer $(P)$ with an inhibitor (Inh), the complex being unstable and capable of decomposition:

$$
\mathrm{P}-\operatorname{lnh} \rightarrow \mathrm{P} \bullet+\operatorname{lnh} \bullet,
$$

and note that it results in the end free macroradical formation. The formation of end macroradicals can also occur at polymer cutting $[149,150]$ that is inevitable in the course of polymer implant fabrication according to a two-stage scheme.

Let us consider some of the results of our study illustrating the main features of the manifestations of the abovementioned conclusions. All polymer and polymer products were prepared by photopolymerization. The use of photopolymerization is explained by the following: 1) the process can be carried out at any temperature under the conditions approximated to isothermal; 2) polymerization initiation rate in this case is equal to the product $\varepsilon_{\lambda} \cdot C_{0} \cdot E_{0}$, it assumes its alteration by varying light intensity $\left(E_{0}\right)\left(C_{0}\right.$ and $\varepsilon_{\lambda}$ are concentration and molecular coefficient of light absorption at wavelength $\lambda$ of a photoinitiator in the composition); 3 ) the change of initiation rate has no effect on the changes of velocity constants of polymerization chain growth and disconnection. 4,4-dimethylphenyl acetophenone was used as a photoinitiator in all compositions.

When oligocarbonate methacrylate of OCM-2 type is photopolymerized (polymerization velocity is proportional to light intensity to the first power), a solid polymer forms with glass transition temperature being about $90^{\circ}$, in which end macroradicals are preserved at a room temperature within $\sim 10$ days, their electron paramagnetic resonance (EPR) spectrum is given in Figure 4 (it is typical for all end macroradicals of methacrylic series $[149,150])$. It indicates there are compositions, the polymerization of which results in the formation of free radicals but not their death. It can be said that these findings suggest breakless polymerization. 


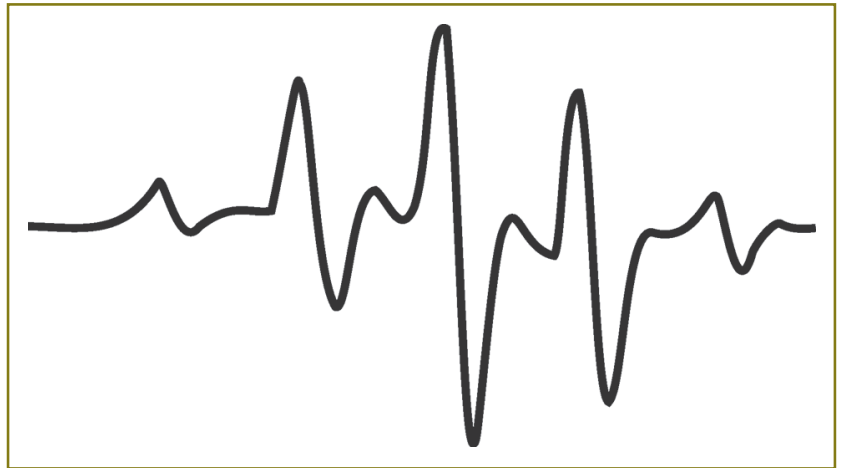

Figure 4. Spectrum of electron paramagnetic resonance of typical end macroradicals at polymerization of oligocarbonate methacrylate of OCM-2 type

However, there are compositions, in which the course of breakless polymerization is not so evident. It concerns the compositions described in [151, 152], which are used to manufacture visco-elastic intraocular lens (glass transition temperature of polymer in such compositions is no more than $-40^{\circ} \mathrm{C}$ ). EPR failed to record free radicals after the polymerization of these compositions. We hardly think it contradicts the breakless polymerization assumption. The main consequences hold true: there is abnormally high polymerization velocity proportional to light intensity to the first power. In these compositions there must be no death of macroradicals resulted from recombination and disproportionation reactions, though their death can be resulted from slower reactions, which compete with polymerization chain disconnection reactions (thermo-oxidative degradation, free valence migration, etc.). It is likely since polymer rigidity in case of these implants is significantly lower than that of implants made of OCM-2.

Figure 5 shows a typical dependence of oligocarbonate methacrylate (TGM-3 type) polymerization velocity in a matrix polymer (butyl methacrylatemethacrylic acid copolymer, the composition of which is indicated in $[153,154])$ on the correlation time of spinning motion of a paramagnetic probe (PP). 2,2,6,6tetramethyl-4-oxypiperidine-1-oxyl was used as PP, different motility of reagents in these compositions was achieved by changing the content of a matrix polymer in them. The curve has its peak at correlation time approximately equal to $6 \cdot 10^{-10} \mathrm{~s}$. The presence of a peak corresponds to the abovementioned consequences: primarily, chain disconnection reactions arrest, then those of their growth.

If the compositions with a matrix polymer on curves showing the dependence of polymerization velocity on PP correlation time have a rather sharp peak, then the compositions with no matrix polymer a peak is significantly wider (the compositions prepared were different in their compositions, their PP correlation times are given in Figure 6. In oligomer-monomer mixtures polymerization velocity increases with viscosity growth

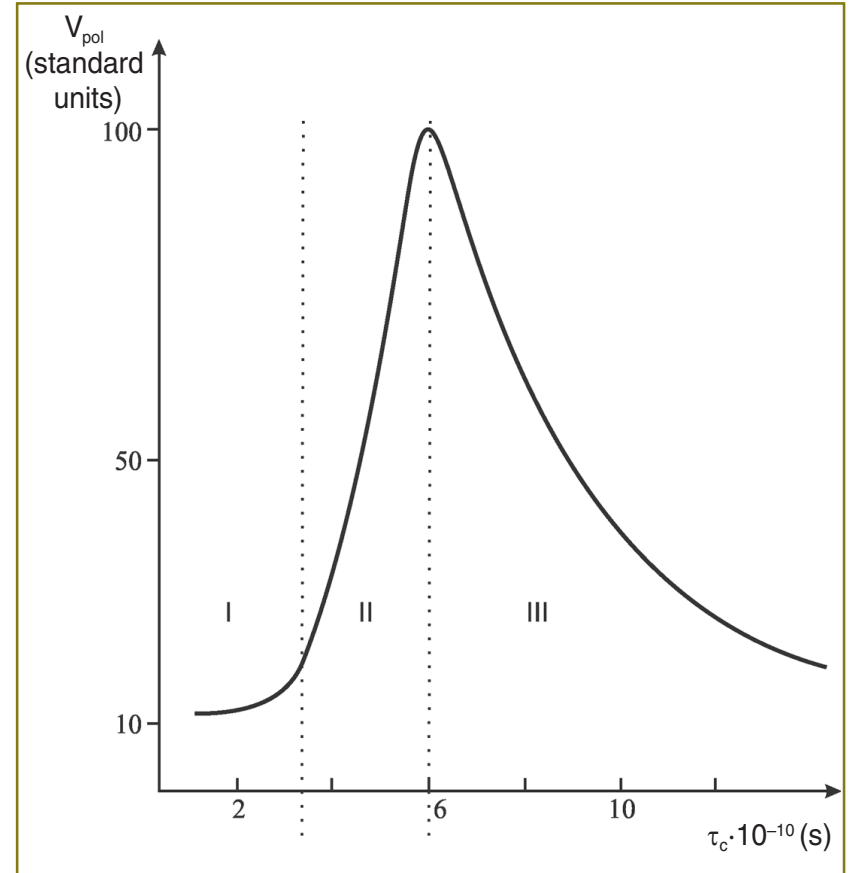

Figure 5. The dependence of oligocarbonate methacrylate (TGM-3 type) polymerization velocity $\left(V_{\text {pol }}\right)$ in a matrix polymer on correlation time $\left(\tau_{c} \cdot 10^{-10}\right)$ of spinning motion of a paramagnetic probe

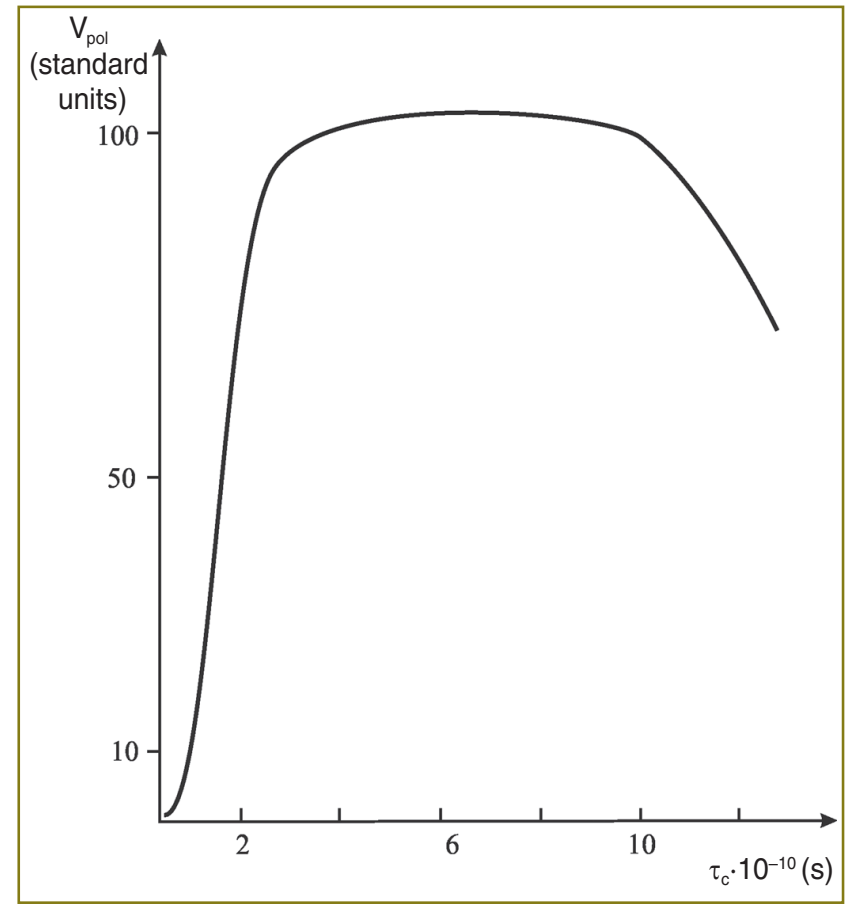

Figure 6. The dependence of polymerization velocity $V_{p o l}$ on correlation time $\left(\tau_{c} \cdot 10^{-10}\right)$ in liquid photopolimerizable compositions composed of different oligomers

(PP correlation time) as well but achieves its maximum values if PP correlation time is $0.5 \cdot 10^{-10} \mathrm{~S}$ rather than $6 \cdot 10^{-10} \mathrm{~s}$ (See Figure 6).

The question arises: what are the reasons for such 
great differences in the curves of dependence of polymerization velocity on reagent motility in compositions with a matrix polymer and those without it? If there is no matrix polymer in a composition and the correlation time is less than $6 \cdot 10^{-10} \mathrm{~s}$, then the oligomer polymerization proceeds primarily according to microheterogeneous mechanism: first, polymer "beads" form followed by their growth and fusion [146]. Beads form due to the fact that oligomers have two or more double bonds resulting in the formation of a spatially cross-linked polymer which loses its capability to dissolve in the initial mixture. The formation of such beads means nothing else but local viscosity increase in the reaction medium that necessitates local change of polymerization velocity in these areas. A layer on the surface of the beads is supposed to form, and the viscosity in the layer is that the polymerization can proceed at abnormally high velocity. In addition, it is reasonable to suggest that PP correlation time in such layer equals $6 \cdot 10^{-10} \mathrm{~S}$ (we shall think that polymerization velocity and reagent motility in "beads" depend on their remoteness from centers, and if the motility of reagents is dropping monotonically when approaching the center, then the dependence of polymerization velocity on remoteness, as shown in Figure 5 , has its peak). If the time value is higher, the polymerization is homogeneous [154]. In fact, there is the breakdown of microheterogeneous polymerization in oligomer-monomer mixtures. It is clear that for this breakdown to occur, the diffusion of components in the mixture at a significantly high rate is necessary. A matrix polymer in compositions acts as a kind of an obstacle to reagent diffusion in a mixture.

It all indicates that the highest polymerization velocity can be achieved only if PP correlation time of the compositions used is not less than $6 \cdot 10^{-10} \mathrm{~s}$, but the formation of end radicals in them is inevitable. If it is troublesome to record them by ESR in some systems, these radicals should be considered to be sure to form though they have time to react and result in the formation of some unstable (labile) products rather than recombine with each other. The presence of free radicals

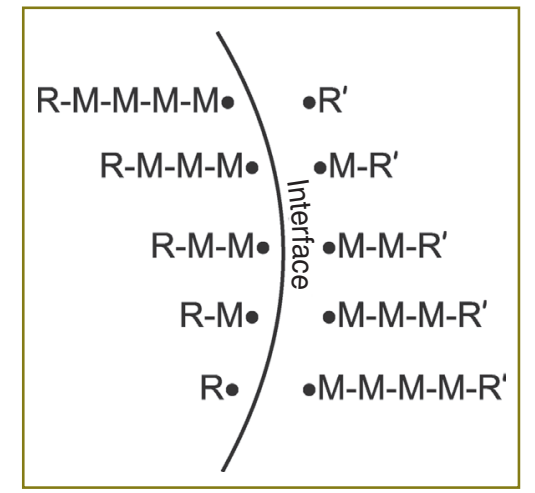

Figure 7. Scheme of a probable mechanism of polymer solution in biologically active liquids and unstable products in a polymer leads to toxicity related to the release of low-molecular substances in the surrounding tissues. The main process in such systems is believed to be the solution of polymers without swelling (by a previously unknown mechanism) due to the two processes simultaneously proceeding at the polymermedium interface: depolymerization and polymerization (Figure 7). These processes require the presence of end macroradicals in a polymer and free radicals in a medium. Free radicals in the environment of a polymer can result from the reactions of proper compounds with free radicals and unstable products in a polymer. Note that the reaction course is competent thermodynamically. From the above described it follows that the presence of free radicals and unstable products in a polymer can lead to toxic reactions.

To negate free radicals and unstable products in implants it is necessary to include an additional stage for their processing. For this purpose we suggest using solvents, which are hydrogen donators (contain a tertiary hydrogen atom - $\mathrm{DH}$, for example, isopropyl alcohol; they can play the role of polymerization chain transmitters rather than inhibitors of polymerization reaction to prevent from the formation of unstable products - PX). The essence of the supplementary stage consists of the following reactions:

$$
\begin{aligned}
& \mathrm{P} \bullet+\mathrm{DH} \rightarrow \mathrm{PH}+\mathrm{D} \bullet ; \\
& \mathrm{P} \bullet+\mathrm{D} \bullet \rightarrow \mathrm{P}-\mathrm{D} \text {; } \\
& \mathrm{PX}+\mathrm{DH} \rightarrow \mathrm{PH}+\mathrm{X}+\mathrm{D} \bullet \text {; } \\
& \mathrm{D} \bullet+\mathrm{D} \bullet \rightarrow \mathrm{D}-\mathrm{D} \text {. }
\end{aligned}
$$

These reactions are carried out in gaseous or liquid phases at boiling temperature of a solvent. Lowmolecular products $X$ and $D-D$ are brought out of implants, for example, by extraction. It should be noted that the stage will cause no difficulties in case of spatially cross-linked polymers and enable to almost completely eliminate the release of low-molecular compounds from implants (See the Table).

Implants, in which polymer molecules do not form a spatially cross-linked structure, can partially solve during the mentioned procedure that eventually can result in abolition of their use.

Optical density of aqueous extract prepared by storing in distilled water at $37^{\circ} \mathrm{C}$ for $72 \mathrm{~h}$ at the rate of $10 \mathrm{mg} / \mathrm{ml}$

\begin{tabular}{cccc}
\hline $\begin{array}{c}\text { Wave- } \\
\text { length } \\
\text { (nm) }\end{array}$ & $\begin{array}{c}\text { Ontical density of aqueous extract (optical density units) } \\
\text { Iens made } \\
\text { of elastic } \\
\text { hydrophobic } \\
\text { acryl }\end{array}$ & $\begin{array}{c}\text { Anti-glaucoma } \\
\text { drainages made } \\
\text { of hydrophilic } \\
\text { acryl (swell } \\
\text { in water) }\end{array}$ & $\begin{array}{c}\text { Endoprostheses } \\
\text { for reconstructive } \\
\text { surgery made } \\
\text { of hydrophobic } \\
\text { acryl }\end{array}$ \\
\hline 200 & 0.06 & 0.04 & 0.08 \\
\hline 210 & 0.04 & 0.02 & 0.06 \\
\hline 220 & 0.02 & 0.01 & 0.05 \\
\hline
\end{tabular}


The introduction of the above described stage eliminates the release of the substances form implants for some time though it does not settle the problem of their biostability. Some compounds from the environment are obvious to be able to diffuse in implants resulting in polymer destruction, and for this reason it will require if not prevent a polymer from destruction then slow the process suddenly. Theoretically, it is possible if hydrophobic polymers (eliminating implant swelling in liquid solutions) are used. There are two equal theories determining the diffusion coefficients of the compounds in media: by means of energy parameters and a free volume value [155]:

$$
D=D_{0} \exp \left(-\frac{E_{D}}{R \cdot T}\right)=\exp \left(-\frac{B}{f}\right) ; \quad f=\frac{V_{f}}{V_{f}+V},
$$

where $D$ is a diffusion coefficient; $V_{f}$ is free volume; $V_{f}+V$ is the reaction medium volume; $E_{D}$ is the energy of diffusive motion activation; $D_{0}$ is a pre-exponential factor; $f$ is fractional free volume; $B$ is a constant; $R$ is a gas constant; $T$ is temperature.

The first equation is generally taken into consideration rather than the second one, but unfortunately, the first equation is unable to show directly the way to solve the problem. The second equation definitely implies that the problem can be solved if to fabricate polymers, the fractional free volume in which is near zero $(f \approx 0)$, at least, formally, swelling in water results in $f$ increase that enables to give preference to hydrophobic polymers rather than hydrophilic ones. More importantly, $D$ decrease should lead to the reduction of $\delta$ parameter, and finally, to the arrest of most reactions in a polymer. This raises the question: what should be the process of implant fabrication for the fractional free volume in a polymer to be as low as practicable?

The polymerization reaction behavior results in both: polymer formation and the formation of heat and free volume:

$$
n \cdot M \rightarrow M_{n}+\text { "heat" + "free volume". }
$$

Heat generation causes the medium temperature increase, and therefore, the growth of "disorder". This condition presupposes the polymerization reaction to proceed at possible low temperatures, it explains, in particular, the transfer to photopolymerization. Free volume forms at any time when a monomer (oligomer) adheres to a macroradical in the form of quasi-particles with zero density, the quasi-particles being the main cause of various voids formed in a polymer, micro-areas with decreased density of polymer package, and other defects. The polymer destruction starts with defects [149], it necessitates to eliminate their formation in implants resulted from the free volume formation. It is difficult to guess what properties a polymer would exhibit if there were no defects in it.

Quasi-particles of free volume have two possibilities: either enter the surface of a reaction medium after diffusion and disappear (result in medium shrinkage), or remain in a polymer. In a polymer quasi-particles can aggregate into defects, for instance by their confluence. The time values of quasi-particle released to the surface of a reaction medium after diffusion are proportional to diffusion linear dimension squared, so the entrance of all quasi-particles from the reaction medium is possible only in case of infinitely thin layers. This conclusion was brought into effect when developing frontal photopolymerization with extreme low depth of the reaction front [105, 125, 156-158]. In contrast to the most known frontal photopolymerization techniques, in this case a conversion front spreads perpendicularly to light rays rather than along them [125]. And in other known frontal photopolymerization methods it is impossible that the reaction front depth could be so small for all free volume particles to leave a polymer.

The principle of our photopolymerization technique is as follows (Figure 8). There are two waves: a light (initiating) wave and a polymerization wave. A sample with the composition enters the reaction area with some constant velocity $\omega$. Lighting should be distributed so that the change from zero lighting to its maximum will occur in an area (layer) with minimum thickness. It can be achieved, in particular, by plunging the samples from air into water, which has higher refraction compared to air (the use of total internal reflection phenomenon). The conditions are selected so that the two indicated waves could move synchronously. It is clear that the only compositions used in front photopolymerization are those, in which polymerization proceeds at abnormally high velocity, i.e., in which the arrested reactions are those of polymerization chain disconnection. There can be other variants of frontal photopolymerization implementation with extreme narrow reaction front width. In particular, the works [156-158] demonstrate the techniques, when light flux moves towards the composition rather than the reverse, though the principle of the techniques is unchanged. Frontal photopolymerization finds its application in manufacturing intraocular lens [156, 157] and other optically transparent products (without defects) [159-163]. Light initiation in this polymerization technique is also explained by the fact that the reaction can be carried out at room temperature, or lower ones.

Defects resulted from the aggregation of free volume quasi-particles cannot be considered as a single cause of defect formation. It has already been mentioned that if PP correlation time is less than $6 \cdot 10^{-10} \mathrm{~s}$, there is microheterogeneous polymerization in the compositions without a matrix polymer, and the formation of optically transparent polymers (without defects) is impossible. The only conclusion can be made: in frontal photopolymerization there should be excluded the compositions, in which PP correlation time is less than $6 \cdot 10^{-10} \mathrm{~s}$. There are also other reasons for the presence of defects in polymers, primarily, it is purity of initial monomers and oligomers, which should contain no inclusions. It is a matter of synthesis of monomers 


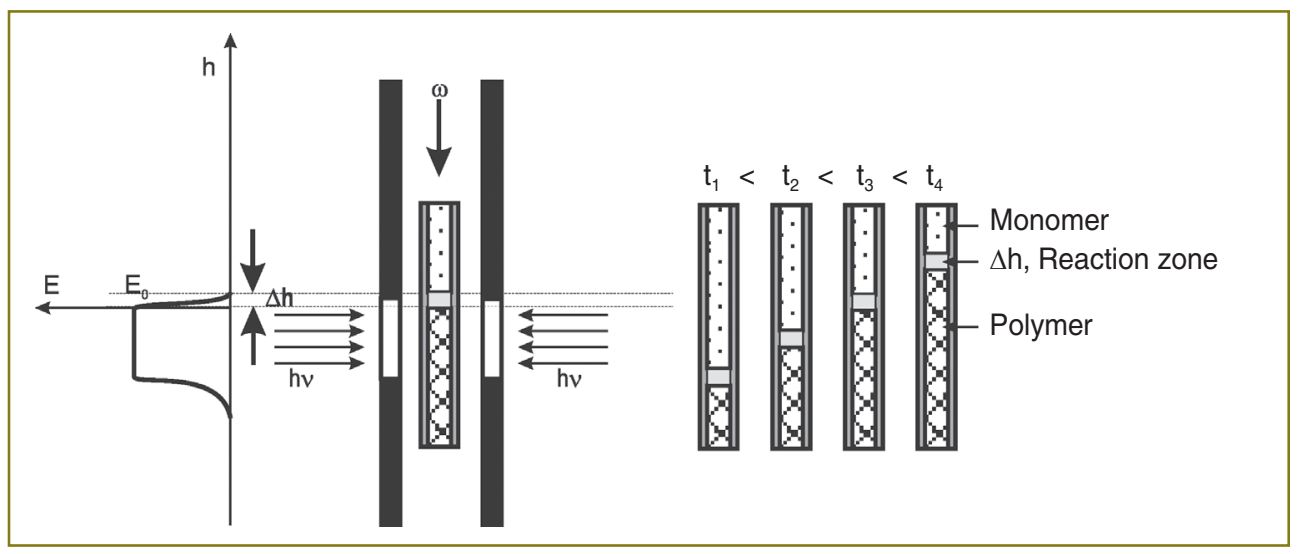

Figure 8. Scheme to realize frontal polymerization processes with infinitesimal reaction front

and oligomers, their synthesis is not considered in the present study.

It can give the impression that frontal photopolymerization with extreme low reaction depth is the only possible way to produce polymers with fewest defects. In some cases biocompatible and biostable polymer implants can be manufactured by both contact and projection photolithography. Using these techniques the layers up to $1 \mathrm{~mm}$ thick can be used to produce implants. The more a layer thickness, the less should be the formation rate of free volume quasi-particles in a mixture (polymerization velocity). The reduction of the process rate can be achieved using the methods related to the decrease of light intensity or photoinitiator concentration, reduced reactive capacity of microradicals rather than by the increase of viscosity in excess of the specified value. It should be noted that the reduction of macroradical reactive capacity can be achieved by adding in a composition special additives, which form complexes with end groups of macroradicals. The efficacy of the mentioned techniques raises no doubts, their principle being the same: to create conditions under which all free volume quasi-particles have time to leave the reaction zone before a polymer completely forms.

There is a special case if polymer formation rate is much higher than that of quasi-particles released from a layer and their confluence resulting in defect formation. It happens, in particular, if the layers are exposed to light, the light intensity being more than some limiting value. The confluence of quasi-particles, as well as all chemical reactions, can stop at sufficiently high viscosity of compositions. The stopping of the process enables to lead to unexpected effects in the future. This is due to the fact that no confluence of quasi-particles results in polymer formation, which can seem optically transparent (the size of quasi-particles is so small that they do not dissipate light: Rayleigh rating), however, a polymer is far from being stable (there is neither release of quasiparticles from a layer nor their confluence in a layer). It stands to reason that a polymer with such properties will aim for a stable state. The process can proceed for many years. In case of intraocular lens, it sometimes leads to the so called secondary cataract (when there is intraocular lens opacity like lens opacity) $[10,12,14$, 16]. The polymer efforts towards a steady state are natural. The course of the process can be accelerated by polymers exposed to femtosecond laser radiation (in terms of photochemistry, here prevail transitions along vibration level rather than electron transitions). The radiation effect on nearly all polymers results in the formation of tracks (traces in a form of lines showing the way of a laser beam). We associate tracking with polymer transition to a steady state in the points of a beam path. It is reasonable since there is no tracking in polymers produced by frontal photopolymerization with extreme low reaction front (this technique enables to manufacture polymers characterized by steady-state density packing).

Conclusion. The review represents basic theoretical aspects, which became the guidelines for developing the techniques to manufacture many polymer implants according to a one-stage scheme $[151,152,156-$ 158, 164-169]. These polymer implants have been manufactured for over 15 years, and are widely used in medicine in Russia and worldwide. They have appeared to be safe, compatible with biological tissues, and it is reasonable to suppose that they exhibit high strength. In fact, here are two main techniques to manufacture biocompatible and biostable polymer implants: frontal photopolymerization with extreme low reaction front, and the technique resulting in the death of end macroradicals and unstable products. It requires the use of compositions, the polymerization of which leads to the formation of hydrophobic spatially cross-linked polymers, and correlation time of spinning motion of a paramagnetic probe is about $6 \cdot 10^{-10} \mathrm{~s}$. Production of implants resulting in no encapsulation presupposes the use of compositions, which have monomers of a methacrylic series, and substituents in which are linear satisfied hydrocarbons with chain length from 8 to 18 carbon atoms, though the 
correlation time of a paramagnetic probe in them should be $6 \cdot 10^{-10} \mathrm{~s}$. The conclusion cannot be made without taking into consideration the phenomena of chemical reaction arresting and reactive capacity leveling, as well as the recognition of the description of chemical reactions under the conditions limiting molecular mobility of reagents. It should also be mentioned that a polymer in biocompatible and biostable implants can be only optically transparent, but the reverse may be not true.

Study Funding. The study was supported by LLC "Reper-NN".

Conflicts of Interest. The authors of the article are employees of LLC "Reper-NN". LLC "Reper-NN" had no impact on data collection and analysis, subediting of the manuscript and the decision on publication.

\section{References}

1. Buckhurst P.J., Naroo S.A., Shah S. Advanced intraocular lens designs. European Ophthalmic Review 2010; 4(1): 82-87.

2. Richter-Mueksch S., Kahraman G., Amon M., SchildBurggasser G., Schauersberger J., Abela-Formanek C. Uveal and capsular biocompatibility after implantation of sharp-edged hydrophilic acrylic, hydrophobic acrylic, and silicone intraocular lenses in eyes with pseudoexfoliation syndrome. J Cataract Refract Surg 2007; 33(8): 1414-1418.

3. Pozdeeva N.A., Pashtaev N.P. Iskusstvennaya iridokhrustalikovaya diafragma $v$ khirurgicheskom lechenii aniridii [Artificial iris-lens diaphragm in surgical treatment of aniridia]. Cheboksary; 2012; 160 p.

4. Pozdeeva N.A. New model of artificial iris-lens diaphragm for correction of large iris defects (clinical and functional results of implantation). Vestnik oftal'mologii 2013; 129(6): 38-44.

5. Iskakov I., Egorova E., Koronkevich V., Lenkova G., Korolkov V., Treushnikov V. Novel diffractive-refractive bifocal IOL: optical properties and earliest clinical results. In: XXIV Congress of the ESCRS (European Society of Cataract and Refractive Surgeons). London; 2006; p. 217.

6. Pashtaev N.P., Pivovarov N.N., Treushnikov V.M., et al. Novaya model' diafragmiruyushchey elastichnoy IOL. V kn.: Sovremennye tekhnologii kataraktal'noy i refraktsionnoy khirurgii - 2011 [A new model of diaphragm elastic IOL. In: Modern technologies of cataract and refractive surgery - 2011]. Moscow; 2011; p. 196-200.

7. Maliugin B.E. State-of-the-art cataract surgery and intraocular optical correction. Vestnik oftal'mologii 2014; 130(6): 80-88.

8. Trubilin V.N., Temirov N.N. Correction of aphakia various origins multifocal intraocular lenses with asymmetric rotational optics. Kataraktal'naya $i$ refraktsionnaya khirurgiya 2014; 4: 20-25.

9. Altynbaeva G.R. Osobennosti vybora mul'tifokal'nykh intraokulyarnykh linz v khirurgii katarakty. Avtoref. dis. ... kand. med. nauk [Peculiarities of choosing multifocal intraocular lens in cataract surgery. PhD Thesis]. Krasnoyarsk; 2012.

10. Mencucci R., Favuzza E., Boccalini C., Gicquel JJ., Raimondi L. Square-edge intraocular lenses and epithelial lens cell proliferation: implications on posterior capsule opacification in an in vitro model. BMC Ophthalmol 2015; 15: 5, http://dx.doi. org/10.1186/1471-2415-15-5.
11. Menapace R., Findl O., Kriechbaum K., LeydoltKoeppl Ch. Accommodating intraocular lenses: a critical review of present and future concepts. Graefes Arch Clin Exp Ophthalmol 2007; 245(4): 473-489, http://dx.doi.org/10.1007/ s00417-006-0391-6.

12. Gutierrez L.G., Rodriguez P., Garcia D.A. Intraoperative opacification of a hydrophilic acrylic with hydrophobic surface IOL with spontaneous resolution in 24 hours. J Refract Surg 2013; 29(5): 360-362, http://dx.doi.org/10.3928/1081597X20130313-03.

13. Sobolev N.P., Malyugin B.E., Pokrovskiy D.F., Patakhova H.M. Surgical experience with angle-supported phakic IOLs for high myopia correction. Oftal'mokhirurgiya 2013; 4: 20-24.

14. Vasavada A.R., Raj S.M., Shah A., Shah G., Vasavada V., Vasavada V. Comparison of posterior capsule opacification with hydrophobic acrylic and hydrophilic acrylic intraocular lenses. J Cataract Refract Surg 2011; 37(6): 1050-1059, http://dx.doi. org/10.1016/j.jcrs.2010.12.060.

15. Maurino V., Allan B.D., Rubin G.S., Bunce C., Xing W., Findl O.; Moorfields IOL Study Group. Quality of vision after bilateral multifocal intraocular lens implantation: a randomized trial - AT LISA 809M versus AcrySof ReSTOR SN6AD1. Ophthalmology 2015; 122(4): 700-710.

16. Nixon D.R., Woodcock M.G. Pattern of posterior capsule opacification models 2 years postoperatively with 2 single-piece acrylic intraocular lenses. J Cataract Refract Surg 2010; 36(6): 929-934, http://dx.doi.org/10.1016/j.jcrs.2009.12.040.

17. Malyugin B.E., Takhtaev Y.V., Morozova T.A., Pozdeeva N.A. Clinical outcomes of the third generation multifocal gradient IOL implantation in prospective multicenter study. Oftal'mokhirurgiya 2012; 2: 36-41.

18. Pashtaev N.P., Bat'kov E.N. The results of implantation of a new model of posterior chamber elastic $\mathrm{OOL}$ in insufficient capsular support. Oftal'mokhirurgiya 2009; 5: 34-39.

19. Kuznetsov S.L., Uzunyan D.G., Zakhidov A.B., Novikov S.V., Selifanov Yu.V. IOL with torsion haptics. Clinical results of volume-substituting model study. Oftal'mokhirurgiya 2010; 2: 24-29.

20. Hengerer F.H., Artal P., Kohnen T., Conrad-Hengerer I. Initial clinical results of a new telescopic IOL implanted in patients with dry age-related macular degeneration. J Refract Surg 2015 Mar; 31(3): 158-162, http://dx.doi.org/10.3928/1081597X20150220-03.

21. Calladine D., Evans J.R., Shah S., Leyland M. Multifocal versus monofocal intraocular lenses after cataract extraction. Sao Paulo Med J 2015; 133(1): 68, http://dx.doi. org/10.1590/1516-3180.20151331T2.

22. Kohnen T., Fabian E., Gerl R., Hunold W., Hütz W., Strobel J., Hoyer H., Mester U. Optic edge design as long-term factor for posterior capsular opacification rates. Ophthalmology 2008; 115(8): 1308-1314, http://dx.doi.org/10.1016/ j.ophtha.2008.01.002.

23. Malyugin B.E., Tereshchenko A.V., Belyy Yu.A., Demyanchenko S.K., Fadeyeva T.V., Isayev M.A. The comparative analysis of spherical and aspherical IOL implantation clinical efficacy. Oftal'mokhirurgiya 2011; 3: 27-31.

24. Dawes L.J., Illingworth C.D., Wormstone I. A fully human in vitro capsular bag model to permit intraocular lens evaluation. Invest Ophthalmol Vis Sci 2012; 53(1): 23-29, http://dx.doi. org/10.1167/iovs.11-8851.

25. Cleary G., Spalton D.J., Zhang J.J., Marshall J. In vitro lens capsule model for investigation of posterior capsule 
opacification. J Cataract Refract Surg 2010; 36(8): 1249-1252, http://dx.doi.org/10.1016/j.jcrs.2010.05.006.

26. Ness P.J., Werner L., Maddula S., Davis D., Zaugg B., Stringham J., Burrow M., Yeh O. Pathology of 219 human cadaver eyes with 1-piece or 3-piece hydrophobic acrylic intraocular lenses: capsular bag opacification and sites of square-edged barrier breach. J Cataract Refract Surg 2011; 37(5): 923-930, http://dx.doi.org/10.1016/j.jcrs.2010.11.036.

27. Roshdy M.M., Riad R.F., Morkos F.F., Hassouna A.K., Wahba S.S. Effect of a single-piece aspheric hydrophobic acrylic intraocular lens design on centration and rotation. J Cataract Refract Surg 2013; 39(3): 408-413, http://dx.doi.org/10.1016/ j.jcrs.2012.09.020.

28. Ghoreishi M., Agherian R., Peyman A.R., Feshareki H., Mohammadinia M. Flexible toric iris claw phakic intraocular lens implantation for myopia and astigmatism. J Ophthalmic Vis Res 2014; 9(2): 174-180.

29. Nixon D.R., Apple D.J. Evaluation of lens epithelial cell migration in vivo at the haptic-optic junction of a one-piece hydrophobic acrylic intraocular lens. Am J Ophthalmol 2006; 142(4): 557-562, http://dx.doi.org/10.1016/j.ajo.2006.05.049.

30. Raj S.M., Vasavada A.R., Kaid J.S., Vasavada V.A., Vasavada V.A. Post-operative capsular pacification. Nepal J Ophthalmol 2009; 1(1): 43-59, http://dx.doi.org/10.3126/ nepjoph.v1i1.3673.

31. Gushchina M.B., Treushnikov V.V., Sorokina O.V. Skleroplantat dlya rekonstruktivnoy skleroplastiki pri patologicheskikh sostoyaniyakh sklery [Scleroplant for reconstructive scleroplasty in sclera pathologies]. RU patent 2460497. 2010.

32. Anisimova S.Yu., Anisimov S.I., Drozdova G.A., Larionov E.V., Ozornina O.S. Results of use of scleroplastic material on the xenocollagen basis in progressing myopia treatment. Rossiyskaya pediatricheskaya oftal'mologiya 2009; 3: $35-38$.

33. Iomdina E.N. Biomekhanika skleral'noy obolochki glaza pri miopii: diagnostika narusheniy $i$ ikh eksperimental'naya korrektsiya. Avtoref. dis. ... dokt. biol. nauk [Biomechanics of sclera membrane in myopia: diagnostics of impairments and their experimental correction. DSc Thesis]. Moscow; 2000.

34. Rada J.A., Shelton S., Norton T.T. The sclera and myopia. Exp Eye Res 2006; 82(2): 185-210, http://dx.doi. org/10.1016/j.exer.2005.08.009.

35. Kuznetsova M.V. Prichiny razvitiya blizorukosti $i$ ee lechenie [Etiology of myopia and its treatment]. Moscow: MEDpress-inform; 2005; 176 p.

36. Filatova G.P. Implantatsiya biologicheskikh materialov pri skleroukreplyayushchikh operatsiyakh (eksperimental'noklinicheskoe issledovanie). Avtoref. dis. ... kand. med. nauk [Implantation of biological materials in sclera restorative surgeries (experimental and clinical study). PhD Thesis]. Moscow; 2009.

37. Neroev V.V., Tarutta E.P., Oganesyan O.G., Penkina A.V., Khandzhyan A.T., Milash S.V. Assessment of the impact of intrastromal corneal segment implantation (Ferrara ring) on the parameters of anterior and posterior corneal curvature using a scheimpflug analyzer Galilei G2. Novoe v oftal'mologii 2014; 2: 60-62.

38. Lam K., Rootman D.B., Lichtinger A., Rootman D.S. Post-LASIK ectasia treated with intrastromal corneal ring segments and corneal crosslinking. Digit J Ophthalmol 2013; 19(1): $1-5$

39. Jadidi K., Mosavi S.A., Nejat F., Naderi M., Janani L., Serahati S. Intrastromal corneal ring segment implantation (keraring $355^{\circ}$ ) in patients with central keratoconus: 6-month follow-up. J Ophthalmol 2015; 2015: 916385, http://dx.doi. org/10.1155/2015/916385.

40. Weber C.H., Cionni R.J. All about capsular tension rings. Curr Opin Ophthalmol 2015; 26(1): 10-15, http://dx.doi. org/10.1097/ICU.0000000000000118.

41. Wilkie D.A., Stone Hoy S., Gemensky-Metzler A., Colitz C.M. Safety study of capsular tension ring use in canine phacoemulsification and IOL implantation. Vet Ophthalmol 2014, http://dx.doi.org/10.1111/vop.12232. [Epub ahead of print].

42. Biró Z., Szabó I., Pámer Z. Combined cataract surgery on a Marfan-syndrome patient (case report). Oftalmologia 2014; 58(2): 30-33.

43. Rodrigo B.J., Paulina L.L., Francesc Mde R., Eduardo T.T., Alejandro N. Intraocular lens subluxation in Marfan syndrome. Open Ophthalmol J 2014; 8: 48-50, http:// dx.doi.org/10.2174/1874364101408010048.

44. Kuznetsov S.L. Vliyanie vnutrikapsul'nogo stabiliziruyushchego kol'tsa na polozhenie intraokulyarnykh linz s ploskostnoy gaptikoy (predvaritel'noe soobshchenie). V kn.: Eroshevskie chteniya: trudy Vserossiyskoy konferentsii [The effect of an intracapsular stabilizing ring on the position of intraocular lens with planar haptics (a preliminary report). In: Eroshevsky readings: proceedings of All-Russia conference]. Samara; 2007; p. 226-229.

45. Kuznetsov S.L. Rezul'taty izucheniya endokapsulyarnykh korrelyatsiy pri implantatsii vnutrikapsul'nykh kolets i IOL s ploskostnoy gaptikoy $\mathrm{v}$ eksperimente. $\mathrm{V}$ kn.: Sovremennye tekhnologii khirurgii katarakty: materialy 5-y Mezhdunarodnoy nauchno-prakticheskoy konferentsii [Results of studying endocapsular correlations when implanting intracapsular rings and IOL with planar haptics in experiment. In: Modern technologies of cataract surgery: proceedings of $5^{\text {th }}$ International research and practice conference]. Moscow; 2004; p. 188-193.

46. Kuznetsov S.L. Rezul'taty implantatsii vnutrikapsul'nykh kolets iz polipropilenovykh nitey $v$ kachestve sredstva dopolnitel'noy fiksatsii IOL s ploskostnoy gaptikoy v eksperimente. V kn.: Glaukoma i drugie problemy oftal'mologii: sbornik nauchnykh trudov, posvyashchennyy 15-letiyu Tambovskogo filiala GU MNTK "MG" im. akademika S.N. Fedorova [Implantation outcomes of intracapsular rings of polypropylene fibers as an adjunctive fixation means for IOL with planar haptics in experiment. In: Glaukoma and other ophthalmological problems: collection of scientific papers devoted to $15^{\text {th }}$ anniversary of Tambov branch of State Institution "Interbranch Scientific and Technical Complex "Eye Microsurgery" named after Academician S.N. Fedorov]. Tambov; 2005; p. 221-227.

47. Fankhauser F. Microincision IOL outcomes positive after a year. EuroTimes 2006; 11(9): 9.

48. Kuznetsov S.L. Results of experimental study of endocapsular correlations of various intracapsular ring models and plate-haptic IOLs. In: XXIV Congress of the ESCRS: abstracts. London; 2006; p. 229.

49. Burger J., Kreutzer T., Alge C.S., Strauss R.W., Eibl K., Haritoglou C., Neubauer A.S., Kampik A., Priglinger S.G. Capsular tension ring-based in vitro capsule opacification model. J Cataract Refract Surg 2008; 34(7): 1167-1172, http://dx.doi. org/10.1016/j.jcrs.2008.03.040.

50. Egorova E.V., Betke A.V., Bezborodov V.G. Mathematical modeling in a solution of the long-term complications problem of cataract surgery with zonular weakness. Oftal'mokhirurgiya 2014; 3: 13-18. 
51. Grinev A.G. Sviridova M.B., Herebtsova O.M., Dolgopolova M.S. Clinical cases of cataract phacoemulsification in eye with small pupil, big hard nuclei and lens subluxation. Ural'skiy meditsinskiy zhurnal 2013; 9: 103-105.

52. loshin I.E. Intracapsular ring in cataract surgery in lens subluxation (15 years experience). Vestnik oftal'mologii 2012; 128(2): 45-49.

53. Malyugin B.E. Malyugin ring. Novoe v oftal'mologii 2013; 4: 59-61.

54. Nizov A.V., Stepanov A.V. The efficiency of Ahmed valve in posttraumatic glaucoma surgery. Kataraktal'naya $i$ refraktsionnaya khirurgiya 2011; 11(4): 52-54.

55. Tereshchenko A.V., Molotkova I.A., Belyy Yu.A., Erokhina E.V. Modification of the modern microinvasive nonpenetrating glaucoma surgery with use of T-shaped drainage. Oftal'mokhirurgiya 2011; 2: 38-42.

56. Galassi F., Giambene B. Deep sclerectomy with SkGel implant: 5-year results. J Glaucoma 2008; 17(1): 52-56, http:// dx.doi.org/10.1097/IJG.0b013e3180d0a885.

57. Bikbov M.M., Babushkin A.E., Chaika O.V., Orenburkina O.I., Matiukhina E.N. Results of fistulizing and Ahmed valve surgery for treatment of refractory glaucoma. Vestnik oftal'mologii 2014; 130(2): 8-11.

58. Vinod K., Frolov M.A., Bozhok E.V., Dushina G.N. Experience in the application of metal drainage of domestic construction in glaucoma surgery. Novoe $v$ oftal'mologii 2012; 4: 43-45.

59. Figus M., Lazzeri S., Fogagnolo P., lester M., Martinelli P., Nardi M. Supraciliary shunt in refractory glaucoma. Br J Ophthalmol 2011; 95(111): 1537-1541, http://dx.doi. org/10.1136/bjophthalmol-2011-300308.

60. Ryazantseva T.V., Kravets L.I. Explantodrainage with nanostructured surface for refractory glaucoma surgery. Byulleten' sibirskoy meditsiny 2012; 11(1): 71-76.

61. Pozdeyeva N.A., Gorbunova N.Y., Pashtayev N.P. Efficacy of valve drainage devices in secondary glaucoma in patients with artificial iridolenticular diaphragm. Vestnik oftal'mologii 2011; 127(4): 41-45.

62. Yevstigneyeva Yu.V. Collagen implant in refractory glaucoma surgery. Vestnik oftal'mologii 2011; 127(1): 36-38.

63. Takhchidi Kh.P., Cheglakov V.Yu. Drainages in refractory glaucoma surgery. Refraktsionnaya khirurgiya i oftal'mologiya 2009; 3: 11-15.

64. Neroev V.V., Bykov V.P., Kvasha O.I., Belevtseva T.A. Micro draining surgery in glaucoma treatment. Literary review. Russkiy meditsinskiy zhurnal 2009; 3: 113-116.

65. Wang H., Dong H., Kang C.G., Lin C., Ye X., Zhao Y.L. Preliminary exploration of the development of a collagenous artificial dura mater for sustained antibiotic release. Chin Med $J$ (Engl) 2013; 126(17): 3329-3333.

66. Lv C., Zhou Z., Song Y., Liu L., Liu H., Gong Q., Li T., Zeng J., Tu C., Pei F. Novel biodegradable lamina for lamina repair and reconstruction. Spine J 2013; 13(12): 1912-1920, http://dx.doi.org/10.1016/j.spinee.2013.06.055.

67. Bai W., Wang X., Yuan W., Wang H., Wang Z. Application of PLGA/type I collagen/chitosan artificial composite dura mater in the treatment of dural injury. J Mater Sci Mater Med 2013; 24(9): 2247-2254, http://dx.doi.org/10.1007/s10856-013-4964-8.

68. Tikhomirov S.E., Tsybusov S.N., Kravets L.Ya., Fraerman A.P., Balmasov A.A. Plasty of the base of the skull defects and dura mater with the reperen's new polymer material. Sovremennye tehnologii v medicine 2010; 2: 6-11.

69. Shesterickov A.A., Lalov Yu.V., Fomin P.A., Uspensky I.V.
Hermetization of the turkish saddle fundus with the "ReperenST" synthetic implant in a combined treatment of the chiasmal and sellar area tumors. Sovremennye tehnologii $v$ medicine 2011; 1 : 6-10.

70. Ivanov S.Y., Zaitsev A.B., Yamurkova N.F., Migura S.A., Gubova V.M., Yantsen I.E., Akulov M.M., Muraev A.A. The study of barrier function of collagen membrane "Osteoplast" in healing bone defects in an experiment. Sovremennye tehnologii $v$ medicine 2011; 3: 35-38.

71. Matsumoto Y., Aikawa H., Tsutsumi M., Narita S., Yoshida H., Etou H., Sakamoto K., Kazekawa K. Histological examination of expanded polytetrafluoroethylene artificial dura mater at 14 years after craniotomy: case report. Neurol Med Chir (Tokyo) 2013; 53(1): 43-46, http://dx.doi.org/10.2176/ nmc.53.43.

72. Uspenskiy I.V., Treushnikov V.V., Sorokina O.V., Tikhomirov S.E., Fraerman A.P., Kravets L.Ya. Implantat dlya plastiki defektov tverdoy mozgovoy obolochki [An implant for dura mater defect plasty]. RU patent 2436596. 2009.

73. Matsumoto Y., Aikawa H., Tsutsumi M., Narita S., Yoshida H., Etou H., Sakamoto K., Kazekawa K. Histological examination of expanded polytetrafluoroethylene artificial dura mater at 14 years after craniotomy: case report. Neurol Med Chir (Tokyo) 2013; 53(1): 43-46, http://dx.doi.org/10.2176/ nmc.53.43.

74. Christoffersen M.W., Brandt E., Helgstrand F., Westen M., Rosenberg J., Kehlet H., Strandfelt P., Bisgaard T. Recurrence rate after absorbable tack fixation of mesh in laparoscopic incisional hernia repair. Br J Surg 2015; 102(5): 541-547, http:// dx.doi.org/10.1002/bjs.9750.

75. Li J., Ji Z., Zhang W., Li L. The comparison of lightweight mesh and standard mesh in incisional hernia repair with the open sublay technique: the results of a meta-analysis. Surg Laparosc Endosc Percutan Tech 2015; 25(3): 238-244, http:// dx.doi.org/10.1097/SLE.0000000000000144.

76. Parshikov V.V., Medvedev A.P., Samsonov A.A., Romanov R.V., Samsonov A.V., Gradusov V.P., Petrov V.V., Khodak V.A., Baburin A.B. Tension-free plasty in the surgery of abdominal wall hernias. Vestnik hirurgii im. I.I. Grekova 2010; 169(5): 74-79.

77. Khodak V.A., Petrov V.V., Dvornikov A.V., Mironov A.A., Baburin A.B., Parshikov V.V., Tsybusov S.N. The possibilities and advantages of sutureless plasty of abdominal wall using different synthetic meshes in experimental study. Sovremennye tehnologii v medicine 2012; 2: 31-36.

78. Sedov V.M., Gostevskoy A.A., Tarbaev S.D., Gorelov A.S., Chulkhovin A.V., Nutfullina G.M., Zhukovsky V. Meshed implants of polyvinylidene fluoride in treatment of abdominal wall hernias. Vestnik hirurgii im. I.I. Grekova 2008; 167(2): 16-21.

79. Rehman S., Khan S., Pervaiz A., Perry E.P. Recurrence of inguinal herniae following removal of infected prosthetic meshes: a review of the literature. Hernia 2012; 16(2): 123-126, http://dx.doi.org/10.1007/s10029-011-0873-2.

80. Fedorov I.V. Prostheses in hernia surgery: the hundred years evolution. Novyy khirurgicheskiy arkhiv 2002; 4(1).

81. Berthet J.P., Canaud L., D’Annoville T. Titanium plates and Dualmesh: a modern combination for reconstructing very large chest wall defects. Ann Thorac Surg 2011; 91(6): 17091716, http://dx.doi.org/10.1016/j.athoracsur.2011.02.014.

82. Zhukovskiy V.A. Polimernye endoprotezy dlya gernioplastiki [Polymer endoprostheses for hernioplasty]. Saint Petersburg: Eskulap; 2011; 104 p. 
83. Averyanov M.Y., Gaar E.V., Gorokhov V.N. Comparative analysis of the use of non-tension and traditional hernioplasty techniques in abdominal hernias of various localizations. Sovremennye tehnologii $v$ medicine 2011; 3: 39-43.

84. Kouhia S., Vironen J., Hakala T., Paajanen H. Open mesh repair for inguinal hernia is safer than laparoscopic repair or open non-mesh repair: a nationwide registry study of complications. World J Surg 2015, http://dx.doi.org/10.1007/ s00268-015-3028-2. [Epub ahead of print].

85. Descloux A., Pohle S., Nocito A., Keerl A. Hybrid NOTES transvaginal intraperitoneal onlay mesh in abdominal wall hernias: an alternative to traditional laparoscopic procedures. Surg Endosc 2015, http://dx.doi.org/10.1007/s00464-0154141-x. [Epub ahead of print].

86. Kathju S., Nistico L., Melton-Kreft R., Lasko L.A., Stoodley P. Direct demonstration of bacterial biofilms on prosthetic mesh after ventral herniorrhaphy. Surg Infect (Larchmt) 2015; 16(1): 45-53, http://dx.doi.org/10.1089/ sur.2014.026.

87. Christmas A.B., Honaker D. Incarcerated massive sliding hernia treated with bladder resection and mesh repair. Am Surg 2015; 81(3): 123-124.

88. Salokorpi N., Sinikumpu J.J., Iber T., Zibo H.N., Areda T., Ylikontiola L., Sándor G.K., Serlo W. Frontal cranial modeling using endocranial resorbable plate fixation in 27 consecutive plagiocephaly and trigonocephaly patients. Childs Nerv Syst 2015, http://dx.doi.org/10.1007/s00381-015-2657-y. [Epub ahead of print].

89. Liebelt B.D., Huang M., Baskin D.S. Sellar floor reconstruction with the Medpor $\AA$ implant versus autologous bone following transnasal transsphenoidal surgery: outcome in 200 consecutive cases. World Neurosurg 2015, http://dx.doi. org/10.1016/j.wneu.2015.02.025. [Epub ahead of print].

90. Durnovo E.A., Khomutinnikova N.E., Mishina N.V., Trofimov A.O. The peculiarities of the reconstruction of the walls of orbital cavity during the treatment of traumatic damages of facial skeleton. Meditsinskiy al'manakh 2013; 5: 159-161.

91. Piitulainen J.M., Kauko T., Aitasalo K.M., Vuorinen V., Vallittu P.K., Posti J.P. Outcomes of cranioplasty with synthetic materials and autologous bone grafts. World Neurosurg 2015; 83(5): 708-714, http://dx.doi.org/10.1016/ j.wneu.2015.01.014.

92. Chaya A., Yoshizawa S., Verdelis K., Myers N., Costello B.J., Chou D.T., Pal S., Maiti S., Kumta P.N., Sfeir C. In vivo study of magnesium plate and screw degradation and bone fracture healing. Acta Biomater 2015; 18: 262-269, http:// dx.doi.org/10.1016/j.actbio.2015.02.010.

93. Kutikov A.B., Skelly J.D., Ayers D.C., Song J. Templated repair of long bone defects in rats with bioactive spiral-wrapped electrospun amphiphilic polymer/hydroxyapatite scaffolds. ACS Appl Mater Interfaces 2015; 7(8): 4890-4901, http://dx.doi. org/10.1021/am508984y.

94. Lu T., Wen J., Qian S., Cao H., Ning C., Pan X., Jiang X., Liu X., Chu P.K. Enhanced osteointegration on tantalum-implanted polyetheretherketone surface with bone-like elastic modulus. Biomaterials 2015; 51: 173-183, http://dx.doi. org/10.1016/j.biomaterials.2015.02.018.

95. Kim I.G., Hwang M.P., Du P., Ko J., Ha C.W., Do S.H., Park K. Bioactive cell-derived matrices combined with polymer mesh scaffold for osteogenesis and bone healing. Biomaterials 2015; 50: 75-86, http://dx.doi.org/10.1016/j.biomaterials.2015. 01.054 .

96. Hinderer S., Shena N., Ringuette L.J., Hansmann J.,
Reinhardt D.P., Brucker S.Y., Davis E.C., Schenke-Layland K. In vitro elastogenesis: instructing human vascular smooth muscle cells to generate an elastic fiber-containing extracellular matrix scaffold. Biomed Mater 2015; 10(3), http://dx.doi. org/10.1088/1748-6041/10/3/034102.

97. Orłowska J., Kurczewska U., Derwińska K., Orłowski W., Orszulak-Michalak D. The use of biodegradable polymers in design of cellular scaffolds. Postepy Hig Med Dosw (Online) 2015 Mar; 69: 294-301, http://dx.doi.org/10.5604/17322693. 1142717.

98. Biosovmestimye materialy [Biocompatible materials]. Pod red. Sevast'yanova V.I., Kirpichnikova M.P. [Sevast'yanova V.I., Kirpichnikov M.P. (editors)]. Moscow: Med. informatsionnoe agentstvo; 2011; 540 p.

99. Gumargalieva K.Z., Zaikov G.E., Moiseev Yu.V. Macrokinetic aspects of polymer biocompatibility and biodegradability. Uspekhi khimii 1994; 63(10): 905-921.

100. Khench L., Dzhons D. Biomaterialy, iskusstvennye organy i inzhiniring tkaney. Seriya "Mir biologii i meditsiny" [Biomaterials, artificial organs and tissue engineering. Issue "World of biology and medicine"]. Moscow: Tekhnosfera; 2007; $304 \mathrm{p}$.

101. Korzhikov V.A., Vlakh E.G., Tennikova T.B. Polymers in orthopedic surgery and tissue engineering: from engineering materials to smart biofunctionalization of a surface. Polymer Science Series A 2012; 54(8): 1203-1221, http://dx.doi. org/10.1134/s0965545x12070036.

102. Rikli D.A., Curtis R., Schilling C., Goldhahn J. Application potential of biodegradable plates and screws for treatment of distal radial bone fractures. Margo Anterior 2002; 4: 1-4.

103. Vallet-Regi M., Colilla M., González B. Medical applications of organic-inorganic hybrid materials within the field of silica-based bioceramics. Chem Soc Rev 2011; 40(2): 596607, http://dx.doi.org/10.1039/c0cs00025f.

104. Treushnikov V.M. Basic principles of biocompatible implant manufacturing. Nizhegorodskie vedomosti meditsiny 2007; 6: 46-55.

105. Valuev L.I., Davydov D.V., Sytov G.A., Valuev I.L. Hydrogel ophthalmic implants. Polymer Science Series A 2014; 56(6): 786-788, http://dx.doi.org/10.1134/ S0965545X1406011X.

106. Treushnikov V.M., Viktorova A. Basic principles of biocompatible implant manufacturing. In: International Symposium "New polymers and radioprotectors for biology and medicine". Yerevan, Armenia, 8-10 October, 2007.

107. Duan Yuan-yuan, Jia Jun, Wang Shao-hai, Yan Wei, Jun Lei, Wang Zhong-yi. Preparation of PLGA electrospun nanofibers for tissue engineering applications. Journal of USChina Medical Science 2007; 4(1, Serial 26): 41-44.

108. Ito Y., Hasuda H., Kamitakahara M., Ohtsuki C., Tanihara M., Kang I.K., Kwon O.H. A composite of hydroxyapatite with electrospun biodegradable nanofibers as tissue engineering. J Biosci Bioeng 2005; 100(1): 43-49, http://dx.doi.org/10.1263/ jbb.100.43.

109. Li M., Mondrinos M.J., Gandhi M.R., Ko F.K., Weiss A.S., Lelkes P.I. Electrospun protein fibers as matrices for tissue engineering. Biomaterials 2005; 26(30): 5999-6008, http:// dx.doi.org/10.1016/j.biomaterials.2005.03.030.

110. Vasilets V.N., Kazbanov I.V., Efimov A.E., Sevastianov V.I. New methods for implant matrix formation based on electrospinning and bioprinting technologies. Vestnik transplantologii i iskusstvennykh organov 2009; 11(2): 47-53.

111. Sevastianov V.I. Biomaterials, drug delivery systems, 
and bioengineering. Vestnik transplantologii $i$ iskusstvennykh organov 2009; 11(3): 69-80.

112. Sevastianov V.I., Vasilets V.N., Agapov I.I. Biopolymer implants for high-technology assistance in the field of replacement and regenerative medicine. Rare metals 2009; 28: 84-86.

113. Bazhenov S.L., Berlin A.A., Kul'kov A.A., Oshmyan V.G. Polimernye kompozitsionnye materialy. Prochnost' i tekhnologii [Polymer composition materials. Strength and technologies]. Moscow: Intellekt; 2009; 352 p.

114. Perepelkin K.E. Armiruyushchie volokna $i$ voloknistye polimernye kompozity [Reinforcing fibers and fibrous polymer composites]. Moscow: Nauchnye osnovy i tekhnologii; 2009; $658 \mathrm{p}$.

115. Zolotareva N.V., Semenov V.V., Myakov V.N., Kulikova T.I., Arapova A.V., Faerman V.I., Gorshkov O.N., Kasatkin A.P., Kotomina V.E., Kruglov A.V., Trushin V.N., Treushnikov V.V., Treushnikov V.M. Formation of microchannes in heat-curable silicone rubber using filamentary crystals of p-aminobenzoic acid. Izvestiya Akademii nauk. Seriya khimicheskaya 2015; 1: 189-195.

116. Wu Y., Dudek S.T., Bamgbade B.A., McHugh M.A. Highpressure phase behavior of boltorn hyperbranched polymers in supercritical fluids. Fluid Phase Equilibria 2014; 382: 180-186, http://dx.doi.org/10.1016/j.fluid.2014.09.010.

117. Popov V.K., Krasnov A.P., Volozhin A.I., Houdl S.M. New bioactive composite materials for bone tissues regeneration. Perspektivnye materialy 2004; 4: 49-57.

118. Mironova L.A. Acrylic basis with Calcium-MAKG supplement. Rossiyskaya stomatologiya 2013; 1: 25-27.

119. Tkachenko V.M. Razrabotka osteointegrativnogo gelya gialuronovaya kislota gidroksiappatit $s$ bakteritsidnymi svoystvami. V kn.: Bolezni tsivilizatsii $v$ aspekte ucheniya V.I. Vernadskogo: materialy 3-y Mezhdunarodnoy konferentsii [Development of osteointegrative gel: hyaluronic acid hydroxylapatite with antibacterial properties. In: Civilization diseases in the terms of V.I. Vernadsky theory: proceedings of $3^{\text {rd }}$ International conference]. Moscow; 2005; p. 317.

120. Antonov E.N., Bagratashvili V.N., Whitaker M.J., Barry J.J., Shakesheff K.M., Konovalov A.N., Popov V.K., Howdle S.M. Three-dimensional bioactive and biodegradable scaffolds fabricated by laser sintering. Adv Mat 2005; 17(3): 327-330, http://dx.doi.org/10.1002/adma.200400838.

121. Antonov E.N., Bagratashvili V.N., Howdle S.M., Konovalov A.N., Popov V.K., Panchenko V.Ya. Fabrication of polymer scaffolds for tissue engineering using surface selective laser sintering. Laser Physics 2006; 16(5): 774-787, http:// dx.doi.org/10.1134/s1054660x06050070.

122. Kanczler J.M., Mirmalek-Sani S.H., Hanley N.A., Ivanov A.L., Barry J.J., Upton C., Shakesheff K.M., Howdle S.M., Antonov E.N., Bagratashvili V.N., Popov V.K., Oreffo R.O. Biocompatibility and osteogenic potential of human fetal femurderived cells on surface selective laser sintered scaffolds. Acta Biomaterialia 2009; 5(6): 2063-2071, http://dx.doi.org/10.1016/ j.actbio.2009.03.010.

123. Panchenko V.Ya. Lazerno-informatsionnye tekhnologii: sostoyanie del, proekty. V kn.: Puti uchenogo. E.P. Velikhov [Laser information technologies: status, projects. In: Career of a scientist: E.P. Velikhov]. Pod red. Smirnova V.P. [Smirnov V.P. (editor)]. Moscow: TIzd-vo NITs "Kurchatovskiy institut"; 2007; p. 293-295.

124. Varadan V., Vinoy K., Dzhoze K. Mir elektroniki VCh MEMS i ikh primenenie [RF MEMS electronics community and their application]. Moscow: Tekhnosfera; 2004; 528 p.
125. Chesnokov S.A. Polimerizatsiya monomerov (met)akrilovogo ryada pod deystviem vidimogo sveta, initsiiruemaya o-khinonami. Avtoref. dis. ... dokt. khim. nauk [Polymerization of monomers of (meth)acrylic series under exposure to visible light initiated by o-quinones. DSc Thesis]. Nizhny Novgorod; 2014.

126. Owen S.C., Shoichet M.S. Design of three-dimensional biomimetic scaffolds. J Biomed Mater Res A 2010; 94(4): 13211331, http://dx.doi.org/10.1002/jbm.a.32834.

127. Everland H., Samuelsen P., Vange J., Clausen C., Gallego M.R. Compositions and methods for augmentation and regeneration of living tissue in a subject. US patent 8,877,246. 2010.

128. Baer Hans U. Matrix and implant for tissue engineering. WO 2014202199. 2014.

129. Rosbach J., Choritz L., Pfeiffer N., Thieme H. Clinical results of encapsulated bleb removal after Ahmed glaucoma valve implants. Dert Ophthalmologe 2013; 110(8): 722-727, http://dx.doi.org/10.1007/s00347-013-2836-8.

130. Vlakh E.G., Korzhikov V.A., Tennikova T.B. Solid-phase systems of biological recognition based on macroporous polymer monoliths. Izvestiya Akademii nauk. Seriya khimicheskaya 2012; 5: 931-956.

131. Mukhina I.V., Tsybusov S.N., Vedunova M.V., Trifonova A.S., Treushnikov V.M., Kolmogorov Yu.N., Treushnikov V.V., Sorokina O.V. Matritsa dlya kletochnoy transplantologii [Matrix for cell transplantology]. RU patent 2521194. 2014.

132. Shlyapintokh E.Ya. Fotokhimicheskie prevrashcheniya $i$ stabilizatsiya polimerov [Photochemical transformation and stabilization of polymers]. Moscow: Khimiya; 1979; 344 p.

133. Emanuel' N.M., Buchachenko A.L. Khimicheskaya fizika molekulyarnogo razrusheniya $i$ stabilizatsii polimerov [Chemical physics of molecular destruction and stabilization of polymers]. Moscow: Nauka; 1988; 366 p.

134. Treushnikov V.M., Chesnokov S.A. Single-stage processes of polymer products photochemical synthesis with optical accuracy. Journal of Photochemistry and Photobiology A: Chemistry 2008; 196:201-209, http://dx.doi.org/10.1016/ j.jphotochem.2007.07.030.

135. Chesnokov S.A., Chechet Yu.V., Cherkasov V.K., Mamysheva O.N., Treushnikov V.M. General conditions and experimental design of sustained frontal photopolymerization in photopolymerizable liquid compositions. Polymer Science. Series A 2008; 50(3): 291-298, http://dx.doi.org/10.1134/ s0965545x08030073.

136. Feller V. Vvedenie $v$ teoriyu veroyatnostey $i$ ee prilozheniya. T. 1 [An introduction to probability theory and its applications. Vol. 1]. Moscow: Mir; 1967; 498 p.

137. Treushnikov V.M., Pyatygin S.S., Opritov V.A. Interpretations of "critical" phenomena in the work of membrane bound enzyme systems based on a continual diffusion model. Biologicheskie membrany 1991; 8(10): 1093-1098.

138. Treushnikov V.M., Pyatygin S.S., Opritov V.A. Application of the continual diffusion model for analysis of the principles of enzymatic reaction rate regulation under membrane conditions. Membrane and Cell Biology 1995; 8(4): 435-446.

139. Pyatygin S.S., Treushnikov V.M., Opritov V.A., Krauz V.O. The phenomenon of negative temperature dependence of adaptive repolarization of high plant cells when exposed to cold. Fiziologiya rasteniy 1996; 43(1): 80-86.

140. Treushnikov V.M., Pyatygin S.S., Opritov V.A., Orlova O.V. The phenomenon of negative temperature 
dependence of enzymatic reactions and its functional role. Vestnik Nizhegorodskogo universiteta im. N.I. Lobachevskogo. Seriya Biologiya 2001; 1(2): 198-207.

141. Treushnikov V.M., Pomerantseva L.L., Zelentsova N.V., Oleynik A.V. O vozmozhnykh putyakh prevrashcheniy kvaziustoychivykh radikal'nykh tsentrov, obrazuyushchikhsya pri fotolize aromaticheskikh azidov $v$ polimernykh matritsakh [Concerning possible transformation pathways of quasi-stable radical centers resulting from photolysis of aromatic azides in polymeric matrices]. Vysokomolekulyarnye soedineniya. Seriya B 1983; 25(5): 327-331.

142. Semenov N.N. Tsepnye reaktsii [Chain reaction]. Moscow: Nauka; 1986; 535 p.

143. Gladyshev G.P., Popov V.A. Radikal'naya polimerizatsiya pri glubokikh stepenyakh prevrashcheniya [Radical polymerization in deep transformations]. Moscow: Nauka; 1974; 243 p.

144. Semchikov Yu.D. Vysokomolekulyarnye soedineniya [High-molecular connections]. Moscow: Akademiya; 2008; 367 p.

145. Berlin A.A., Kefeli T.Ya., Korolev G.V. Poliefirakrilaty [Polyester acrylate]. Moscow: Nauka; 1967; 374 p.

146. Berlin A.A., Korolev G.V., Kefeli T.Ya., Severgin Ya.M. Akrilovye oligomery i materialy na ikh osnove [Acrylic oligomers and materials on their base]. Moscow: Khimiya; 1983; 238 p.

147. Korolev G.V., Mogilevich M.M., Il'in A.A. Assotsiatsiya zhidkikh organicheskikh soedineniy [Association of liquid organic compounds]. Moscow: Mir; 2002; 264 p.

148. Grishin D.F., Semyonycheva L.L. Problems of control of the reactivity of macroradicals and the growth of polymer chains. Russian Chemical Reviews 2001; 70(5): 425-447, http://dx.doi. org/10.1070/RC2001v070n05ABEH000635.

149. Kaush G. Razrushenie polimerov [Destruction of polymers]. Moscow: Mir; 1981; $440 \mathrm{p}$.

150. Butyagin P.Yu., Dubinskaya A.M., Radtsig V.A. Electron spin resonance spectra, conformation, and chemical properties of free radicals in solid polymers. Russian Chemical Reviews 1969; 38(4): 290-305, http://dx.doi.org/10.1070/ RC1969v038n04ABEH001742.

151. Fedorov S.N., Linnik L.F., Treushnikov V.M., Viktorova E.A. Elastichnyy iskusstvennyy khrustalik i sposob ego izgotovleniya [Flexible artificial lens and its fabrication method]. RU patent 2074673. 1995.

152. Fedorov S.N., Linnik L.F., Treushnikov V.M., Viktorova E.A., Karavaev A.A. Elastichnyy iskusstvennyy khrustalik glaza [Flexible artificial eye lens]. RU patent 2129880. 1999.

153. Treushnikov V.M., Zueva T.A., Esin S.A., Oleynik A.V. Zhurnal nauchnoy i prikladnoy fotografii i kinematografii 1990; 34(3): 167-172.

154. Treushnikov V.M. Esin S.A., Zueva T.A., Semchikov Yu.D., Knyazeva T.E., Yanin A.M., Semenova O.M. Kinetic features of radical polymerization in thin layers of photopolimerizable compositions. Vysokomolekulyarnye soedineniya. Seriya A 1995; 37(12): 1191-1197.

155. Frenkel Ya.l. Kineticheskaya teoriya zhidkosti [Kinetic theory of liquid]. Moscow: Nauka; 1975; 592 p.

156. Fedorov S.N., Linnik L.F., Treushnikov V.M., Viktorova E.A., Karavaev A.A. Sposob izgotovleniya elastichnykh iskusstvennykh khrustalikov glaza [A fabrication method of flexible artificial eye lens]. RU patent 2129846. 1999.

157. Treushnikov V.M., Viktorova E.A. Sposob izgotovleniya elastichnykh iskusstvennykh khrustalikov glaza [A fabrication method of flexible artificial eye lens]. RU patent 2198630. 2003.

158. Treushnikov V.M., Viktorova E.A. Sposob izgotovleniya elastichnykh iskusstvennykh khrustalikov glaza [A fabrication method of flexible artificial eye lens]. RU patent 2234417. 2004.

159. Klapshina L.G., Douglas W.E., Grigoryev I.S., Korytin A.I., Lavrentiev S.A., Lopatin M.A., et al. Novel metaltemplate assembled highly-functionalized cyanoporphyrazine ytterbium and vanadium complexes for potential photonic and optoelectronic applications. J Mater Chem 2009; 19(22): 36683676, http://dx.doi.org/10.1039/b821667c.

160. Domrachev G.A., Semenov V.V., Klapshina L.G., Baten'Kin M.A., Arapova A.V., Kirillov A.I., Lopatin M.A., Obyedkov A.M., Zolotareva N.V., Gorshkov O.N., Kasatkin A.P., Mikhailov A.N., Antonov I.N., Sidorenko K.V., Treushnikov V.M., Treushnikov V.V. The light-emitting and optical properties of high-optical-quality organic glasses doped with europium tris(benzoyltrifluoroacetonate). Nanotechnologies in Russia 2009; 4(3-4): 225-236, http://dx.doi.org/10.1134/ s1995078009030100.

161.Semenov V.V., Zolotareva N.V., Lopatin M.A., Faerman V.I., Domrachev G.A., Gorshkov O.N., Kasatkin A.P., Skamnitskii D.V., Shenina M.E., Kruglov A.V., Treushnikov V.M., Treushnikov V.V. Spectral and optical properties of high-opticalquality organic glasses under prolonged ultraviolet irradiation. Polymer Science. Series A 2010; 52(6): 599-609, http://dx.doi. org/10.1134/s0965545×10060052.

162. Grigoryev I.S., Klapshina L.G., Lermontova S.A., Semenov V.V., Treushnikov V.M., Treushnikov V.V., Bushuk B.A., Clement S., Douglas W.E. Efficient luminescent solar concentrators based on defectless organic glasses containing novel ytterbium cyanoporphyrazine complex. Nanotechnologies in Russia 2012; 7(9-10): 492-498, http:// dx.doi.org/10.1134/s1995078012050059.

163. Molodnyakov S.P., Treushnikov V.V., Treushnikov V.M., Gorshkov O.N., Kasatkin A.P., Shenina M.E., Shushunov A.N., Kruglov A.V., Semenov V.V. Polymeric waveguides based on photopolymerizing methacrylate compositions. Russian Journal of Applied Chemistry 2014; 87(3): 331-335, http://dx.doi. org/10.1134/S1070427214030148.

164. Pashtaev N.P., Pozdeeva H.A., Starostina O.V., Morozova V.H. Iridokhrustalikovaya diafragma $i$ sposob ee izgotovleniya [Iris-lens diaphragm and the process of its manufacturing]. RU patent 2526245. 2013.

165. Tsybusov S.N., Durnovo E.A., Khomutinnikova N.E., Treushnikov V.M., Viktorova E.A., Treushnikov V.V., Sorokina O.V. Matritsa dlya regeneratsii myagkikh tkaney [Matrix for soft tissue regeneration]. RU patent 2526182. 2013.

166. Pashtaev N.P., Pivovarov N.N., Pashtaev A.N., Surkova E.N., Treushnikov V.M., Starostina O.V. Elastichnaya intraokulyarnaya linza [Flexible intraocular lens]. RU patent 2485916. 2011.

167. Gushchina M.B., Treushnikov V.V. Implantat orbital'nyy [Orbital implant]. RU patent 2504348. 2011.

168. Abelevich A.I., Ovchinnikov E.A., Treushnikov V.M., Treushnikov V.V., Sorokina O.V. Endoprotez dlya lecheniya parakolostomicheskikh gryzh [Endoprosthesis for paracolostomal hernia treatment]. RU patent 2503430. 2012.

169. Khomutinnikova N.E., Durnovo E.A., Treushnikov V.M., Treushnikov V.V., Sorokina O.V. Implantat dlya plastiki posttravmaticheskikh defektov i deformatsiy dna i stenok glaznitsy [Implant for plastic repair of posttraumatic defects and orbital fundus and wall deformities]. RU patent 2487726. 2011. 